\title{
Toward a New Politics of Legal Education
}

\author{
Paul N. Savoy†
}

We do not have to wait for the great, visibly cracking structures of our society to collapse eventually. Every single one has already gone-government, law, politics, society itself, the family, the Church, education. What of these appears still to stand is illusion, a mechanical automaton whirring on a dead momentum.

\section{The Winter of Discontent}

-Elizabeth Sewel1

The student revolts that have rocked campuses across the country have left the law schools relatively untouched. This is a social phenomenon that is not difficult to understand. Law and revolution have never made very congenial bedfellows. The observations made by De Tocqueville about the nature of the legal spirit in America are as valid today as they were when he wrote:

Men who have more especially devoted themselves to legal pursuits derive from these occupations certain habits of order, a taste for formalties, and a kind of instinctive regard for the regular connection of ideas, which naturally render them very hostile to the revolutionary spirit. ${ }^{2}$

In a more recent commentary upon the psychodynamics of legal education, Andrew Watson has identified among law students a greater than average need for order and security, a factor which plays a critical role in their functioning both in the academic milieu and later in their professional lives. ${ }^{3}$

What is surprising, and for me, uplifting is the dramatic, if belated, appearance of a small but articulate minority of law students who have begun to express a profound dissatisfaction with legal education that may be more pervasive than any of us have imagined. ${ }^{4}$ That is not to

$\dagger$ Acting Professor of Law, University of California at Davis. B.A. 1960, LL.H. 1969, Columbia University.

1. Sewell, First Reports from an Experimental College, $4 \mathrm{~J}$. of Berravianat Sarenor: 351 (1968).

2. A. De Tocoueville, Democracy in AMerica 171 (H. Commager cd. 1947).

3. Watson, The Quest for Professional Competence: Psychological Aspects of Legal Education, 37 U. CINN, L. REv. 93, 101 (1968).

4. For example, in her valedictory address at the Hastings Law School Commenccinent in June 1969, Jennie Rhine raised more than a few eyebrows when she wondered aloud if these "last three years [had] not been, to a large extent, a waste of my time." For the most part, she said, her legal education had not been "a challenging or rewarding $\mathrm{ex}$ - 
say that administrators or law professors have been unaware of certain deficiencies of contemporary legal education or have failed to undertake measures to remedy them. But the climate of educational reform has had about it that smug satisfaction and bland assurance that proceeds from the assumption that those who teach know what is best for those who learn. Of course, there are student representatives on many of our committees, but nobody really expects them to tell us what to teach or how to teach it, and even if they try, we outnumber them, so we can either bludgeon them into submission or simply outvote them. And while we give students representation on the Curriculum Committee and the Faculty-Student Relations Committee, we exclude them from participation in making decisions about faculty recruitment, tenure, promotion and the budget. And the sadness of it all is that they are so eternally grateful to us for our magnanimous tokenism. As one teacher has expressed it, some students "recognize their put-on for what it is and even let their rebellion break through to the surface now and then," but others have been more deeply brain-

perience," and she made it clear that she was "not alone in fecling this way" that "almost all of us come to regard law school only as an ordeal-something to be survived so that one can get on to more important things." Peter Westen, in an intervicy in 1968, when he was editor-in-chief of the Law Review of the University of California at Berkeley, described how he had come to law school with an image of the lawyer as a social engineer only to find that, in the second and third years, "the school taughe us ... to think less of social horizons than of bread and butter." IVesten Tells it Lihe It Is!, The Writ, April 1, 1968, at 1. At the University of Californis at Davis, several newsletters circulated by a small group of activist law students who ironically called themselves "The Silent Majority" criticized their legal education as "devoid of dimension" and "wholly inadequate in the face of today's ever-pressing problems," urging students to "assume the responsibility placed on us by our times." In an editorial in the Columbia Law School News, a student wrote: "The other day in a class, the professor noted in passing that the purpose of law school is not to teach the myriad intricacies of the law, but rather to give the students a rery broad outlook on law and related social problems. By his own standards, Columbia Law School fails dismally." Fitch, Bitching, Columbia Law School News, Jan. 13, 1969, at 5. In an effort to reform the curriculum, the Black Law Students Union at Yale has proposed new courses designed to treat problems relevant to black lawyers and their clients, including a seminar on "Black Business," a course in "Economic Strategies for the Black Community," and a program in "The American Tax System" which "would examine how the present Federal tax structure has permitted the entrenchment of the wealthiest classes and the corporations, while cxacting a disproportionate share of tax revenue from poorer people, and from the middle class." BLSU Course Proposals for Yale Law School, BLACR LAw STUdents UNioN Joumial, 1968-69, at 3. A law student at the University of Wisconsin, after a series of in-depth interviews with first year law students, tentatively concluded that the "century old method of legal instruction ... causes unnecessary stress and underachievement ... [and] that testing procedures already employed deprive the profession of creative, energetic, and valuable personalities." Silver, Anxiety and the First Semester of Law School, 1908 W15. L. REv. 1201, 1218. At Harvard Law School, a memorandum that reflected the victs of 150 first-year students expressed the conviction that the grading system "draws critical distinctions among students prematurely, at the expense of developing talents over a three-year period ... [and] is a detrimental force in the lives of many first-jear students ...." Members of the Class of 1971, The Trouble With Grades, 1969, at 1 (unpublished document on file in Yale Law Library). 
washed and can't see "what all the fuss is about because Mr. Charlie 'treats us real good.' "'

I recall what it was like being a law student. That incredible boredom of the second and third years drove me from the classroom into the sanctuary of the Law Review where I sought an intense involvement and an excitement that the rest of the law school did not offer. The major difference between me then and dissident students today, I suspect, is that I lacked the cultural maturity or whatever gift it is that enables them to see things as they really are. I had always been convinced that there might have been something wrong with $m e$ and never dreamed that $I$ had the right to expect something more from professors whose authority I never dared to challenge.

There is not a single lawyer I know with whom I went to law school who feels that his legal education adequately prepared him for the practice of law (or anything else for that matter). My experience in one of the larger post-graduate educational institutions in Americathe New York District Attorney's Office-was sobering. Trying to reconstruct an incident from interviews with witnesses; awakening to the ritualistic performance of police officers on the witness stand; plumbing the subleties of the plea-bargaining process; learning the nuances of communication between judges and attorneys, I became suddenly aware of the unforgivable irrelevance of my legal education to what was happening in my head, in the courtroom and in the streets of our cities. The first case I tried was a numbing experience. My only consolation was that the Legal Aid lawyer who represented the clefendant was as woefully untutored as I. Together, we waged a relentless battle of almost metaphysical absurdity: the implacable innocence of Charlic Brown versus the invincible ignorance of Lucy. ${ }^{6}$

It would be unfair to suggest that law schools today (or at lenst the "better" schools) are unaware of what Dean Manning has called that "endless agenda of unfinished business" facing the legal profes.

5. J. Farber, The Student as Nigger, 1967, at 2 (mimcographed document on file in Yale Law Library). "The saddest cases among both black slaves and student slaves are the ones who have so thoroughly introjected their masters' values that thelr anger is all turned inward .... These are the students] for whom cvery low grade is torturc, who stammer and shake when they speak to a professor, who go through an emotional crisis every time they're called upon during class. You can recognize them casily at finals time. Their faces are festooned with fresh pimples; their bowels boil audibly across the room. If there really is a Last Judgment, the parents and teachers who created these wrecks are going to burn in hell." Id. 3. See also, E. Friedenberg, Coming of AGE in AMizias 9-10 (1963).

6. I owe the metaphor to Edgar Friedenberg. Id. 181. 
sion. ${ }^{7}$ Faculty memoranda, law review articles, building dedication ceremonies and conferences such as the American Assembly on Law and the Changing Society held in 1968 and the Symposium on Issues in Legal Education sponsored last year by the Conference of WVestern Law Schools attest to an ongoing concern about the directions in which we are moving in legal education. But the genius of our educational institutions-to adapt an observation of a former president of the American Bar Association-is to make accommodations to shifting objectives "without profound or radical changes in fundamentals." There may be wisdom in a strategy of gradualism, but we ought at least to stop deceiving ourselves about the limits of our tolerance for experimentation. If we want to make only those changes that are certified as wise by those members of the faculty who are "marked by maturity and experience," 9 we ought at least to end our colluding with each other in the delusion that we are engaged in real innovation. Making change on the basis of "informed" and "mature" opinion, as William Arrowsmith has said, will almost inevitably have the effect of stifling reform, if only because informed and mature opinion is "unadventurous and tyrannous as well as profoundly snobbish." 10 And, finally, let us stop conning students into believing that they have something to say about their legal education. Students (and young professors, I might add) resent members of the faculty who invite them to say what they want but refuse to take them or their ideas seriously. Unless we begin to understand that, our efforts to establish an authentic dialogue with students or among ourselves will never move beyond the pious incantation of academic bullshit.

For myself, the only way to grow is to take risks and experiment. Good schools, like happy marriages, are not made in heaven or plotted at monthly meetings. Effective learning cannot be summoned or commanded. It is the felicitous but quite fortuitous result of encounters of teachers with students, of students with students, of teachers with teachers, on issues that teachers are really interested in and students give a damn about. "Within pretty wide limits of utter triviality," Paul Goodman has suggested wisely, "there can be good education that

7. Manning, Introduction: New Tashs for Lawjers, in LAW IN A ChANGwic AMEna

1 (G. Hazard ed. 1968).

8. Gossett, Balances and Controls in Prizale Policy and Decision-ifaling, in id. 26.

9. Manning, supra note 7 , at 1 .

10. Arrowsmith, The Future of Teaching, in CAsrovs 1980, at 124 (A. Eurich ed. 196S). 
is 'general' or 'specialist,' 'liberal' or 'useful,' ... ['emphirical' or 'theoretical']."11

If any real learning is to go on in our schools (and I take it that is what we are all concerned about), then our first responsibility must be to the human beings who live in our academic house, not to the Bar, or the profession, or the alumni. That means that much of our academic planning must involve not the shaping of something called the "curriculum" but the removal of blocks and resistances within the educational organism so that students are free to achieve their own levels of integration. As long as we continue to see legal education as the acquisition of marketable skills, it will never cease to be anything more than a dreary task for a future payoff.

\section{The Sources and Significance of Student Discontent}

A number of assumptions about the "generation gap" and the new student revolts are circulating as counterfeit currency in formal and informal exchanges among faculty and ought to be dispelled if we are to understand the significance of student unrest. One of them portrays dissent as "maladjustment" or "acting out." It is said that student activists are rebelling against parental values and just want to give poor old dad a good kick in the pants by flaunting the authority of the University. However, most reliable studies suggest that student activists are not rebelling against their parents. On the contrary, they "seem to be acting in conformity with their parents' [intellectual and humanitarian] values," but are seeking to implement them in "a purer, less compromising, and more energetic way." 12 Student activists today, then, may be acting out the collective dream of liberal parents who, as Jerome Skolnick has pointed out, have adopted a style of "private attack and public prudence, of private animosity and public acceptance"- a life style that might well warrant the charge of hypocrisy. ${ }^{13}$ America's education, like its politics, has denied our most secret long* ings, and as Peter Marin has suggested, they have come round to haunt us in the person of our students who "gather, with their simplistic (1964).

11. P. Goodman, Compulsory Mis-epucation and the Communtty of Scholars 814

12. J. Katz, The Student Activists: Rights, Needs and Powers of Undergradtates (1967), quoted in Sanford, The College Student of 19S0, in CAMPus 1980, at 185 ( $\Lambda$. Eurich ed. 1968). See J. Katz, The Activist Revolution of 1964, in No TIME For Yourn 886, $\$ 99$ (J. Katz ed. 1968); K. KENNISTON, Young RADicAls: Notrs ON CoMnitred Yourti 298 (1968).

13. Skolnick, The Generation Gap, Trans-Action, Nov. 1968, at 4. 
moral certainty, at the gates of our universities." 14 A day of reckoning is at hand. It may be time to pay our debts to our hearts.

Another popular myth has it that student activists are the "dregs" of the academic community; that our "best" students are waiting in the wings for the rebels to finish their little melodrama of discontent so that they can deliver their orations of praise for the "good job" we are all doing. The evidence indicates, however, that while the dissident group is small, its members, "even by conventional standards . . . [are] among the more highly achieving [students] in the University."10 Among the major findings of the research conducted to date are that activists score significantly higher in "academic aptitude and performance" and that, measured by a variety of personality tests, they emerge as more realistic and tolerant, less authoritarian, and more intellectually and aesthetically oriented than their peers. ${ }^{16}$ As for many of the non-activists, test results show them to be more "success-oriented, . . . conventional [and] competitive."17 One study conducted at Berkeley describes them as "intellectually disengaged" and "discouragingly indifferent," exhibiting a "passive and even cheerless acceptance of conditions as they are, almost whatever they are."18

Another myth of liberal ideology that has been used to explain away student unrest in the university is the "generation gap"- -the idea that what all the trouble is about is simply a "mutual misunderstanding," a temporary failure of communication. Edgar Friedenberg has made a persuasive case for the position that what appears as mere cultural lag in adults responding to a new social and political maturity in the young is rather "the expression of what has become genuine class-conflict between a dominant and exploitative older generation and youth who are slowly becoming aware of what is happening to them ...."'10

14. Marin, The Open Truth and Fiery Vehemence of Youth, Center Aracazane, Feb. 1969, at 64. Laurence Kirschbaum, in a recent book on student unrest, rrites of all those parents, teachers and administrators "who are trying in their own perverse way to make sense out of what has happened-whether, in fact, youth has gone crazy. Lilie my father," he says, "they can read Marcuse, they can recite the arguments, they can deplore the Vietnam war, or oppose $A B M$, or support Gene AfCCarthy. But they vion't Ict themselves feel the real hate, because they've poured their best jears into raising this generation and they won't admit that their molds no longer work." $R$. RApororr \& $L$. KirSCHBAUM, Is THE LIBRARY BuRNmG? 179 (1969).

15. J. Katz, The Activist Revolution of 1964, supro note 12, at 400 .

16. Id. 399; J. Katz, The Student Activists: Rights, Needs and Powers of Undergraduates, supra note 12 , at $184-85$.

17. Id.

18. M. Trow, The Large Campus as a Context for Learning (mimeo 1968).

19. Friedenberg, The Generation Gap, 382 ANwaLs 32, 33 (1969). Once young people begin to realize what is happening to them and attempt to communicate their perceptions to their brothers and sisters, repressive measures are undertaken by the dominant adult community. See Scoville v. Board of Educ., 286 F. Supp. 988 (N.D. Ill. 1968), up- 
The discontented students in our current law school classes are raising not only a direct challenge to the viability of our educational institutions, but a frontal assault upon certain venerable legal doctrines nourished by middle-class liberal values. For students who have experienced the Free Speech Movement at Berkeley, the march on the Pentagon, the Democratic National Convention in Chicago, the rebellion at Columbia and the confrontation over People's Park in Berkeley -to say nothing of the countless number of demonstrations, protest: and draft resistance movements that have struck almost every campus in the country-the refusal of the law to accord the same degree of constitutional protection to symbolic conduct that it has conferred upon conventional speech is an insistence that lawful speech be lifeless speech. Thus, the recent decision of the Supreme Court in the draftcard $^{20}$ cases and its timid opinions in the flag-burningis and black armbands $^{22}$ cases are not merely "unhappy" chapters in the chronicles of a liberal Court. ${ }^{23}$ They are powerful satires of the mystifying rhetoric of political repression. The time-honored liberal distinction between "speech" and "conduct," as Walter Berns has pointed out, is a legalistic vehicle for convicting persons for speech that the government regards as dangerous. ${ }^{24}$ That old liberal standby of the "man . . . falsely shout.

holding the expulsion of students who had circulated a literary journal objecting to school attendance regulations as "utterly idiotic and asinine," noting that "our whole: system of education with all its arbitrary rules and schedules seems dedicated to nothing but wasting time," and urging students in the future "to either refuse to accept or destroy upon acceptance all propaganda that ... [the high school] administration publishes." Id. at 989. The students were punished for expressing views about public eduction that Edgar Friedenberg, Paul Goodman and others have been elaborating for the past ten years. See, e.g., E. Friedenberg, Coming of Age in AMErica 41-2 (1965); P. GoodmaN, Compulsory Mis-Education and THE Comiunity of Scholars 51.63 (196.).

The action of the school administration and the court in Scoville confirms Friedell* berg's observation that the schools help see to it "that the kind of pcople who get alicad are the kind who will support the social system it represents, while those who inight, through intent or merely by their being, subvert it, are left behind as a salutary moral lesson." E. Friedenberc, supra this note, at 49. See also Burnside v. Byars, 363 F.2d 744, $748-49$ (5 Cir. 1966) ("'S]chool rules which assign students to a particular class, forbid unnecessary discussion in the classroom and prohibit the exchange of conversation between students are reasonable .... Obedience to duly constituted authority . . . must bo instilled in our young people.").

20. United States v. O'Brien, 391 U.S. 367 (1968).

21. Street v. New York, 394 U.S. 576 (1969).

22. Tinker v. Des Moines Independent Community School District, 893 U.S. 503 (1969). Within the space of ten pages, the Court emphasized no less than thirtcen scp). arate times that there was no evidence of "aggressive" or "violent" or "disruptive" con" duct or anything else that would result in "interference with school work or discipline" or create "disturbances or disorders on the school premises" or "intrude in the school affairs of the lives of others" or otherwise cause any member of the school community the slightest distress or deprive him of a moment's sleep. 393 U.S. at 505-14.

23. Cf. Alfange, Free Speech and Symbolic Conduct: The Draft-Card Burning Gase, 1968 SUPREME COURT REVIEW 1.

24. W. Berns, Freedom, Virtue and the First AMENDMENt 56 (1965). 
ing fire in a theatre and causing a panic"'s is rushed in every time there is a hint that the speaker is about to move his body or yours. Of course, Holmes never said anything about shouting fire and mobilizing action when the house is burning down.

In a recent article on the rebellion at Columbia, Eric Bentley has eschewed the niceties of legalistic reasoning in reminding us that it is important to keep radical ideas out of the realm of action "not only because one is against them but also because one knows they are vitiated by being reduced to a purely verbal existence."20 But, more to the point, there seems to be within the heart of the liberal temperament an implacable hostility toward the mode of expression rather than the content of radical protest. The medium of radical politics, to adapt McLuhan, is its message. What I am suggesting is not that fatuous liberal distinction between "violent protest" and "peaceful dissent." "Violence" and "disorder" have come to mean in the rhetoric of liberal debate those expressions of emotions that cannot be readily tamed or manipulated by the liberal imagination. "Breaches of the peace" and "criminal trespass"- the rubrics under which much radical dissent has been punished-are not as harmful to the person or property of others as they are disruptive of the complacency with which many members of the adult population experience the world and the things that are in it. In my father's house, a breach of the King's Peace was not so much a threat to his property as it was an assault upon his peace of mind.

The new style of political expression-in its emotional intensity and improvisational spirit, in its nonverbal and erotic expressiveness, and its sense of participation and community-is closer to radical theatre than it is to the town meeting that provided Professor Meiklejohn with his model of political freedom. ${ }^{27}$ It is, in Norman Mailer's provocative phrase, "revolution by theater and without a script,"-2s and it is profoundly disorienting. For a culture that has been accustomed to speech that Paul Goodman has described as "insensitive, prosy, affectless, mo. notonous, stereotyped in content, inflexible in rhetorical attitude, mechanical in syntax" 29 -in short, a speech that has been cut off from ourselves - the style of radical politics is indeed violent, in the way in

25. Schenck v. United States, 249 U.S. 47, 52 (1919).

26. Bentley, The Unliberated University, 5 NEw AM. REv. 81, 95 (1969).

27. A. Meikiejohn, Poltical Freedom: The Constitutional Powers of the People 247 (1965).

28. N. Matier, The ARMIIEs of the Night 247 (1968).

29. F. Perls, R. Hefferline \& P. Goodacan, Gestalt Tuerapx: Excmestent and Groitth in the Human Personality 321 (1951). 
which explosions into anger, joy, tears and orgasm are violent. The energies of activist youth, the tidal movements of militant racial groups and the radical life styles of the Hippies, the Yippies, Ken Kesey's Merry Pranksters and other parapolitical groups are generating new dimensions of sensibility and political consciousness that cannot, and will not, be pressed into legal molds that were made for another age. ${ }^{30}$ Underlying the sit-ins, the demonstrations, the draft-card burnings, guerilla theatre (e.g., burning money at Wall Street; removing the arms from the clock in Grand Central Station; the Big Pie Prank at the opening of the San Francisco Film Festival), the underground newspapers, the music of protest, and rock festivals like Woodstock, are the seeds of radically new communities, public arenas (or "theatres of the street'), and modes of communication that are developing in the midst of (and in burlesque of) the traditional political forums-the town meetings, the "marketplace" of ideas, the convention, the com. mittee system, the lecture hall. At the heart of this new movement is a reaction against what Susan Sontag in her essay Against Interpretation has described as "the hypertrophy of the intellect at the expense of energy and sensual capability." 31

We continue to talk about the first amendment in Constitutional Law classes as if street-corner speeches, letters-to-your-Congressinan, pamphleteering, petitions, and letters-to-the-editor were still effective forms of political dissent. One need only to have observed the 1968

30. See Jerome, The American Academy 1970, Chunge in Highen Education, Sept.-Oct. 1969, at 32: "The youth class intends to overthrow a way of life embodied in us-the beneficiaries of the present system. They want to get us at the gut level, and that is where they have aimed, flouting us with their dope [see Leary v. United States, 895 U.S. 6, 41 \&: n.78 (1969)], and rock [see Ferrell v. Dallas Independent School Dist., 393 F.2d 697, $(5$ Cir.), cert. denied, $89 \mathrm{~S}$. Ct. 545 (1968)] and obscenity [see Goldberg v. Regents of University of California, 57 Cal. Rptr. 463 (Dist. Ct. App. (1967)] and hair [sec Breen v. Kaht, 296 F. Supp. 702, 705 and n.3 (W.D. Wis. 1969)]." See generally Friedenberg, The Revolt Against Democracy, Change, May-June 1969, at 12 ("Potblowing is idcological"); $H$. DRAPER, Berkeley: The Student Revolt 140.42 (discussing the ideology of the "lilithy Speech Movement"); Rosenstone, "The Times They Are A-Changin" ": The Music of Pro. test, 382 AnNaLs 131 (1969).

One commentator has explained the political function of long hair, freaky clothes and drugs as follows:

Precisely because the established order today is so pervasive and encompassing . . .

it is not only directly powerful but also enomously absorptive and hard to con.

front. It takes extreme behavior and attitudes to establish and make stick any dif-

ference from and opposition to such a system. There seems to be no effective way

to be moderately different and independent. For this reason, beyond and in addition

to any other values and functions, the characteristic features of the drug move-

ment's life style-not only long haix and odd costumes but especially the open uso

of drugs-must not only be different from the ordinary but blatantly so. High visibil.

ity of the withdrawal from straight society is essential for the movement's cxistence.

Weakland, Hippies: What the Scene Means, in SocuetY AND DRUCs 343, 365 (R. Blun cd. 1969).

31. S. Sontag, Against Interpretation and Other Essiys 7 (1966). 
Democratic National Convention or to have followed the strategies devised by national leaders to manipulate public opinion through the mass media with respect to United States policy in Vietnam to realize that as a method of effecting social and political change, the traditional forms are dead.,32 The difficulty is that while all speakers are free to express their views, not all can speak with equal effectiveness. As one court has suggested, when loudspeakers take the form of television and other electronic media, "a debate in which only one party has the financial resources ... to purchase sustained access to the mass communications media is not a fair test of either an argument's truth or its innate popular appeal." 33 When the law fails to recognize new media of protest-the language of the theatre and the drama of the streets, forms of expression that many citizens find interfere with their normal "peace and quiet"-that failure, in effect, constitutes a decision to silence a new politics, however neutral the legal rhetoric in which the policy of repression is wrapped may appear. Moreover, some of those citizens deserve to have their quiet disturbed. If we are to have a viable constitutional theory of political expression, we must be prepared to include among our models of human communication the radical theatre, the new media, and the therapeutic community.

On another level, viewing the "generation gap" as a manifestation of class conflict may move us toward a reassessment of our assumptions about those laws that have served the adult population so well and so long in regulating "the well-being of its children." here merely of providing young people with lawyers in juvenile courts or other procedural safeguards, ${ }^{35}$ but of beginning to dismantle the entire legal apparatus regulating the conduct of adolescents. Laws making it an offense for a seventeen-year-old to be "idle" moral"37 or "dissolute"38 or "habitually disobedient"39 or "truant" "uncontrolled" 41 raise very serious questions about the extent to which young people, as a systematically discriminated-against minority, have been denied the equal protection of the law. Intolerably vague, most of

32. Cf. N. Postman \& G. Wemgartaner, Teaching as a Subversive Activm 8 (1969).

33. Banzhaf v. F.C.C., 405 F.2d 1082, 1102 (D.C. Cir. 1968), cert. denied, 90 S. Ct. 50. (1969).

34. Ginsberg v. New York, 390 U.S. 629, 639 (1968).

35. Cf. In re Gault, 387 U.S. I (1967).

36. CAL. WEL. \& INST. CODE § 601 (West 1966)

37. Id.

38. Id.

39. ARIZ. REV. STAT. \& 8-201(6)(b).

40. Id. § 8-201(6)(c).

41. Id. § 8-201(6)(b). 
these categories have no objective behavioral criteria, but represent the lunatic efforts of parents, teachers and police to trap the energies of the young in a grid of adult expectations that have been drained of any sense of growth or life. ${ }^{42}$ Even those types of juvenile offenses that correspond to categories of adult criminality-malicious mischief, joyriding, assault, petty theft and sexual offenses-are rarely manifestations of a commitment to a criminal career. ${ }^{43}$ More often, they are the vehicles through which an adolescent strains to achieve his own identity and confirm his sexuality, to experience and sharpen the boundaries of his body and the limits of his self. ${ }^{44}$ The boys, as Lemert ${ }^{45}$ and others have pointed out, are often punished for "hell[ing] around" or "living it up" or "giving the old man a taste of his own medicine." As for the girls, Berger in Hair is more direct: they're "busted for [their] beauty." 46 If our juvenile courts, as they are presently administered,

42. See Friedenberg, The Image of the Adolescent Minority, in E. Friedennerc, TuE Dignrry of YouTH \& OTHER ATAvisMs 66, $69-70$ (1965): "In my experience, it is just not possible to discuss adolescence with a group of American adults without being forced into the topic of juvenile delinquency. Partly this is an expression of legitimate concern, but partly it is because only the JD has any emotional vividness to them... They hate and fear the kinds of spontaneity [and sexuality] that remind them of what they have aban. doned, and they hate themselves for having joined forces with and having come to re. semble their oppressors .... I am convinced that [this] is ... the source of the specific hostility - and sometimes sentimentality - that adolescents arouse in adults. See Board of Directors v. Green, 259 Iowa 1260, 147 N.W.2d 854 (1967) (school regulation cxcluding mar. ried students from participation in extracurricular activities); State ex rel. Idle v. Cham* berlin, 12, Ohio Misc. 44, 175 N.E.2d 539 (C.P. 1961) (school board rule requiring pregnant students to withdraw from school attendance); Perry v. Grenada Mun. Separate School Dist., Civ. No. W.C. 6736 (N.D. Miss., Dec. 27, 1967) (exclusion of unwed mother from school "as a threat to the moral health ... of all other teenage girls."); Ferrell v. Dallas Independent School Dist., 261 F. Supp. 545 (N.D. Tex. 1966), aff'd, 393 F.2d 697 (5 Cir.). cert. denied, $89 \mathrm{~S}$. Ct. 98 (1968) (upholding school rule prohibiting long hair as valid regulation of "lewd" appearance). See generally S. Goldstein, The Scope and Sources of School Board Authority to Regulate Student Conduct and Stalus: A Nonconstitulional Analysis, 117 U. PA. L. REv. 373, 405-25 (1969).

43. See D. Matza, Delinquency and Drift 22 (1964).

44. See Erikson, Identity $v$. Identity Diffusion in Adolescence in NEW PERspectivs Fon Research on Juvenile Delinguency 9-10 (H. Witmer \& R. Kotinsky eds,, 1956); W. Glas. SER, REALITY THERAPY 85 (1965).

45. President's Commission on LaW Enforcement and Administration of Justige, TASK Force Report: Juvenile Delinguency and Crime, 91, 94 (1967).

46. From the song Donna in Hair, copyright 1967-68 James Rado, Gerome Ragni, Galt McDermot, Nat Shapiro, United Artists Music Co. Inc. The Children's Bureati reported that almost 10 per cent of the referrals of girls to court in delinquency cases in 1962 were in the category of "sex offenses" (exclusive of forcible rape), while another 18 per cent were classified as "ungovernable" and 25 per cent as "runaways." U.S. Cuit. Dren's Bureau, Stat. Series No. 73, Table 5 (1963), reprinted in C. Foote, R. Levy \& F. Sander, Cases and Materials on Family Law 396 (1966). The latter two categorics frequently involve some kind of sexual escapade. See A. Cicourel, THE SoGinL OrGANIZATION OF JUVENILE Justice 119 (1968); Reiss, Sexual Offenses: The Marginal stalus of the Adolescent, in SExuAl Deviance 47 (J. Gagnon \& W. Simons eds. 1967).

Edgar Friedenberg has pointed out that our society represses its awareness of the adolescent girl, even though the media are saturated with her image. "[G]irls, like Jews," he observes, "are not supposed to fight back; we expect them, instead, to insinuate them. selves coyly into the roles available. In our society, there are such lovely things for them 
are accomplishing anything, they are transforming the energies of the young into delinquent careers. ${ }^{47}$

The administration of mass compulsory education itself presents profound issues about the viability of institutions that, after prisons and mental hospitals, house the most coercive, deforming and humiliating environments in our culture. Peter Marin, in one of the best articles that I know of on youth in our culture, has described how our fractured visions of adolescence, if not of life itself, have produced a legal and educational system that has attempted to freeze young people into a state of "prolonged childhood . . . that resists change even as the culture itself and its needs shift radically." 18 The problem, Marin writes, is that our institutions "are geared to another century, another set of social necessities, and cannot change quickly enough to contain, receive, or direct [our youth] -and as we supress or refuse them they turn to rage." $₫ 9$

\section{Toward a Humanistic View of Legal Education}

"You must think first."

"But it came out fine."

"It might not have," and all the terrible things that might have happened are explained to me, and I am told that I must look into all the possibilities and not take the chances that I do.

to be. They can take care of other people and clean up after thcin. YYounen can become wives and mothers; Jews can become kindly old Rabbis and philosophers and even psychoanalysts and lovable comic essayists. They can become powers behind the power; a fine old law firm runs on the brains of its anonymous young Jews just as a husband's best asset is his loyal and unobtrusive wife. A Jewish girl can become a Jewish mother, and this is a role which even Plato would have called essential." Friedenberg. The Image of the Adolescent Minority, supra note 42 , at 75-76 (1965). Cf. Dufies $v$. Duifics, 75 Wis. 374,45 N.W. 522 (1890) ("The wife is more domestic [than the husband] .... She is purer and better by nature than her husband, and more governed by principle and a sense of duty and right, and she seldom violates her marriage obligations, or abandons her home."). See generally Reiss, supra this note, at 50.51.

47. See E. Erikson, Identity: Youth and Crists 254-56 (1968); F. Tanaesianua, Came AND THE Comprunity 19-20 (1938).

48. Marin, The Open Truth and Fieny Vehemence of Youth, Center Magazine, Feb. 1969 , at 61,66 .

49. Id. 64. The "solutions" put forth by lawyers to the "problem of student unrest," which is seen as a form of "social pathology" have been "Iegalistic sets of rules and procedures for 'communication' . . . and elaboration of legal techniques-from the injunction to calling the National Guard-to be used when such rules are violated." Lauter \& Alex-

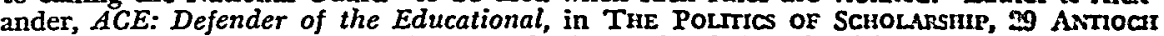
REvIEw 287, 301 (1969). The point that the "procedural liberals" fil to grasp is that the issue is not "communication" or "tactics" or "procedure," but change in the relationships between the students and the University and between the University and other institutions. See Schwartz, Comment, in Symposium on Legal Aspects of Student-Institutional Relationships, 45 DENver L.J. 525 (1968). For one of the few sane perceptions of the role of the law in responding to student protest, see Farer, The Army of Sanclions, in Studest PROTEST AND THE LAW 67 (G. Holmes ed. 1969). 
"Always later, later, later ("when I retire") for life and living, for what sings in me in the beginning and later fizzles to a whimper. Pie-in-the-sky-laughed out of the hereafter and accepted here on earth as making sense.

"Can't we ever live now?"

-Barry Stevens ${ }^{50}$

There has been an incredible volume of literature published in the last twenty years about law school education. The overwhelming concern, however, is with curriculum, methodology and casebooks. We rarely hear anything about teaching. ${ }^{51} \mathrm{I}$ am not talking about that bag of tricks called classroom "techniques"-any fool can learn them in time-but about teaching as that "complex and perilous relationship between a teacher and his student" 52 _ as an honest meeting between man and man. There is not much meeting or sharing or enjoying in our law schools. There's no time for it. We're so busy planning for the future-for the future careers of students, for our own future careers as teachers, for the destiny of the law school-that we have no time to live in the now.

When I first came to teaching two years ago, I had it in mind to emulate the style of some of my own teachers whose verbal art had made them so deadly, so omnipotent in the classroom. But, I find that pedagogical mimesis - teaching as an imitation of teaching-does not work very well for me. The only time that anything really happens in my classes is when I start being the person I really am-with feelings, doubts, expectations, fears-and not the incarnation of some professional or academic role. Lawyers and law students, though, are especially resistant to efforts to get them in touch with their feelings. Of all the admonitions of the Greek philosopher, the one which we self-styled Socratics most persistently and flagrantly ignore is: Know thyself. Between law teacher and law student there is a silent conspiracy to preserve what Alan Watts calls "the taboo against knowing who you are."53

Teachers and students must meet face to face, but that will never

50. C. Rogers \& B. Stevens, Person to Person: The Problem of Being Human 43.44 (1967).

51. Among the new exceptions are Hutchins, The University Law School, in Trw LAW ScHoor OF TOMORROW (D. Haber \& J. Cohen eds. 1968); Reich, Toward the Humanistic Study of Law, 74 YALE L.J. 1402 (1965); Watson, The Quest for Profcssional Compatonct: Psychological Aspects of Legal Education, 37 U. CrNN. L. REv. 93 (1968).

52. S. Shapiro, The Student and the Teacher: Face to Face 2 (mimeographed document on file in Yale Law Library).

53. A. WATTS, THE BOOK (1967). 
happen until we remove our academic masks and put an end to those degradation ceremonies we politely call the "Socratic method." At a time when law students throughout the country are expressing profound dissatisfaction with the second and third years in the house that Langdell built, we might take notice of John Holt's dictum regarding education in our elementary schools which applies with equal force to our law schools: students outplayed or overplayed at the word game will after awhile simply stop playing it. ${ }^{\text {th }}$

\section{The "Socratic Method" and Other Games}

One problem with the "Socratic method" as it is usually practiced is the failure at some point to make explicit for students the nature of the strategies we use to defeat them or the processes by which they defeat themselves. ${ }^{55} \mathrm{We}$ expose students to intellectual battle without ever providing them with an arsenal of skills, and that seems a little unfair, especially when we stay up half the night writing and rehearsing the script for the military drama we stage the next day. Or else, if we are more experienced in the art, we take a few more risks with a little less preparation, but we still expect a student to learn the skill ritualistically-by subjecting him to the initiation rites of public humiliation, sarcasm and ridicule. There is something about that form of pedagogy that is a little like teaching a physics student Newton's laws of motion by dropping him from a third story window or running him down the street. I am not suggesting that we coddle him into competence or that we not expose him to the experiential drama of vigorous discourse, but that we stop practicing the dialectical art in a way that conceals more art than it reveals.

The Socratic method, as it is usually administered in the classroom, consists largely of a set of "games," the most popular of which is "Gorner," "56 a strategy that bears a striking resemblance to the ancient ploys of Zen masters. ${ }^{57}$ The objective in each case is to drive the student into a corner by refuting any position he takes. In being presented with a zoan (a Zen question) or a Socratic question, the student is cast on the horns of a dilemma: he is made to feel that there is some answer

54. J. Holt, Introduction to H. KoHL, TeACHING THE "UNTEACHABLE" 9 (1967).

55. One Iuminous exception is the pioneering course, "Law, Language and Ethics" taught by Christopher Stone and William Bishin at the University of Southern California Law School. See Reisman, In Memory of Harold WW. Soloman: Comments on Southern California's Flyer in Legal Education, 41 S. CAL. L. REV. 506 (1908).

56. See E. Berne, GaAIEs People Play 92-5 (1964). See generally E Benne, Transac. TIONAL ANALYSIS IN PSYChOTHERAPY (1961).

57. See A. WATts, Psychotherapy EAST \& WIST 148-61 (1969). 
he must find, but in seeking it out, he begins to despair of finding it because everything he says is rejected as wrong. This is a version of the "double-bind" first described by Gregory Bateson and his colleagutes in an article entitled Toward a Theory of Schizophrenia. ${ }^{58}$ The feelings experienced by a student exposed to this double-binding have been described as follows:

By careful questioning the dialectician finds out what ... [the student's] opinion is, and then challenges the student to propose and defend it. Naturally, the defense fails, and to the degree that the student is emotionally dependent upon his opinion, he begins to feel insecure, not just intellectually but psychologically and even physically. He therefore looks about him for some other premise to which he can hold, but as he takes up such alternatives the dialectician disposes of them one after another. At this point the student begins to feel a kind of vertigo because it seems that he has no basis from which to think and act, ... . Left to himself in this predicament, he might well go out of his mind. . .50

Here is the experience described by a first-year law student:

Well, Professor $[\mathrm{X}] \ldots$ is unprincipled, he will never let you know which side he is on. He usually gets the kids angered in class because he never lets them know what's right. He says he's just up there to ask questions. He could drive you mad asking all the questions he does. ... ${ }^{60}$

Bateson and others have demonstrated that "double-binding" in parent-child communications is a significant etiological factor in the development of schizophrenic conditions in children. Are we also driving our students mad in the classroom by subjecting them to this paradoxical form of communication?

The difference between the use of the zoan and the purpose of the Socratic dialogue is that the intention of the Zen master is not to teach the student a method for winning arguments, but to demonstrate the futility of argument:

When you stop thinking about the answer, you will stop asking the question. ${ }^{61}$

The Zen game, then, is actually a counter-game, a game to end games. Practiced in this way, with the Zen master there to assure the student,

58. Bateson, Jackson, Haley \& Weakland, Toward a Theory of Schizophrenia, 1 BE* HAVIORAL SCIENCE 251 (1956).

59. A. WaTrs, supra note 57 , at 161 .

60. Silver, Anxiety and the First Semester of Law School, 1968 Wis. L. REv. 1201, 1203.

61. A. WATTS, supra note 57, at 147; see A. WATIS, THE WAX of ZEN 126.33 (1957). 
"not by argument, but by personality, that it is possible to have passed through this crisis with gain rather than loss of sanity, 02 the game of "Corner" can be a therapy that has the effect of liberating the student from his efforts to intellectualize his experience. Used as a method of intellectual inquiry, it is a form of mental illness. The potential uses of this dialogue between teacher and student thus present us with the alternatives of enlightenment and madness: the classroom as carnival (a game-house), asylum (a mad-house) or therapeutic community (a house of learning).

A variation of the game of "Corner" is "One-up":

Student: "Do you think that custodial interrogation in the absence of counsel is a violation of the dignity of the individual?"

Teacher: "What do you mean by 'dignity'?"

The student wants to know where his teacher stands on the issue of providing people with lawyers. The teacher evades the question by changing the subject to philosophy. ${ }^{63}$ The student can never win. The teacher is always one-up. If the student presses the question, he loses because he has "failed" to define his terms. If he switches to philosophy, his inquiry has been derailed. Nor can he comment about what the teacher is doing for, in the classroom, metacommunication is tantamount to insubordination.

Then there is the familiar "chamber of horrors" gambit-the logical paradigm of which is the reductio ad absurdum argument-or what I prefer to call the game of "Now I've Got You, You Son-Of-A-Bitch." "Os By the time a law student reaches his second year, he knows the game and either stops playing it, plays along cynically, or initiates the counter-game of "Wooden Leg"cs ("What can you expect of a 'dumb' student like me") or a variation of "Gee, You're Wonderful, Professor."6s Another popular pasttime of professors that often passes for Socratic dialogue is the game of "Guess What I'm Thinking"; the student counter-game is "Mindreading I, II or III," depending on the number of previous courses the student has had with the professor. When frustration reaches the boiling point in the third year and breaks out in the form of criticism or rebellion, the faculty game becomes "But Look How Hard I'm Trying." "G

62. A. M'ATTS, supra note 57, at 161 .

63. Cf. E. Berne, Games Prople Play $94-95$ (1964).

64. Cf. id. 85-86.

65. Cf. id. 159-62.

66. Cf. id. 152-53.

67. Cf. id. 106-07. 
We pride ourselves in teaching students how to "think like lawyers." But our present educational processes do more to effect thought reform than to offer instruction in logical analysis. Teaching how to "think like a lawyer" is closer to building character than it is to constructing syllogisms. That captivating phrase defines not an intellectual process, but a process of socialization enforced by putting students through some form of suffering and aimed at the production of reliable and predictable people who will be readily assimilated into the Bar Association. ${ }^{68}$

The first year, of course, is critical. The Socratic dialogue at that point has many of the properties of a "degradation ceremony," 00 designed as it is to accomplish the ritualistic destruction of prior modes of classroom behavior and their replacement with a standardized pattern of response through the public humiliation of deviant students. I have seen exceptionally creative students emerge from classes in pieces after having been decimated by the ridicule of a professor. There is little consolation that $I$, or anyone else, can offer them for the outrage and humiliation they have experienced in the presence of their peers. I know they are bright and capable, but their classroom experiences tell them they are dull and stupid. Even the "good" students are casualties of the system. There are thousands of them in our law schools who are just marking time, waiting to graduate, who will pass through the portals of our academies so perfectly untouched by anything that has happened within its walls that the recollection of their lives there will be like the memory of a dreamless sleep.

If real learning is to take place, we must begin with a radical reassessment of our ideas about education; I mean start from the beginning. In the beginning-in kindergarten (literally, "garden of children," a place where children grow)-life is learning and learning is life. But as the individual moves through the educational system, he becomes increasingly estranged from the sources of life. In our elementary and secondary schools, the compartmentalization of experience begins: learning is learning and life is life. In college, learning is anti-learning and life is learning. Finally, in our professional schools, learning becomes anti-life (a manipulation of life) and life becomes

68. See Moore, Occupational Socialization, in HANDBOOK OF SOcLALIZATION THEOHY AND RESEARCH 861, 878-79 (D. Goslin ed. 1968).

69. See Garfinkel, Conditions of Successful Degradation Ceremonies, 61 AM. J. So. croLocy 420 (1956). 
anti-learning (the end of life). ${ }^{70}$ In the rush to meet the deadlines we have set for ourselves, to get a-head, to move up, we lose touch with our selves.

What we need is an awareness and understanding of the emotional landscape of the educational environment-a rediscovery of the wellsprings of human growth where all potential for real learning resides. The trouble with our existing forms of education is that they are anchored to a dualistic vision of man that forces the splitting and polarization of "intellect" and "feeling," of "mind" and "body." To be rational, to control yourself, to be objective and uninvolved, is good. To be irrational, to lose your head, to be subjective and emotionally involved, is bad.

If we insist upon denying what is part of us, of cutting off our hearts and living in our heads, then we commit ourselves to an especially pernicious form of madness. To be suffering from schizophrenia is, literally, to be suffering from a broken heart.

There is much talk about maturity and adaptation, about the need to adjust to reality. Ronald Laing, ${ }^{71}$ Frederick Perls, ${ }^{72}$ George Leon$\operatorname{ard}^{73}$ and others, however, have begun to challenge our conventional notions about normality and maturity, about the effect of families and schools upon our children and students. The contemporary family, Laing suggests, functions as a vehicle through which the experience of children is invalidated by the mystifying rhetoric of love, discipline, and morality, and through which they are encouraged to experience life in substantially the same way as everyone else. ${ }^{74}$ Our schools have a similar effect: to delude students out of their own personal worlds; to persuade them that their personal fantasies are psychopathic while our "socially shared hallucinations" are sane:

At least some of us have managed to hate what [our parents and teachers] have made of us. Inevitably we see ... [them] as the reflection ... of our own self-division .... [but they already] have become installed in our hearts, and we call them ourselves. ${ }^{10}$

70. Cf. Kasamets, Eight Edicts on Education with Eighteen Elaborations, 2 Sounce: Music of the AvaNT GARDE 37, 41 (1968).

71. R. LAING, The Polmics of Experience (1967).

72. F. Perls, Gestalt Therapy Verbatil (1969); F. Perls, R. Hefrerline, P. Goodaran, Gestalt Therapy: Excttement and Growth in the HuMan personality (1951).

73. G. LEONARD, Education AND ECSTASY (1968).

74. R. LAING, supra note 71, at 57-76; Laing, IIystification, Confusion, and Conflict, in INTENSIVE FAMIIY THERAPY 343 (I. Boszormenyi-Nagy \& J. Framo eds. 1965).

75. R. LaIng, supra note 71, at 74. 
There remains somehow an imagination, a passion, an enormous potential for learning in students that can be unlocked if only they are permitted to be themselves, if only we start conceiving of knowledge as a function of inner experience rather than a surrender to orthodoxy or whatever it is that students can be cajoled, conned or hypnotized into accepting as "reasonable:"

Even broken hearts have been known to mend if only we have the heart to let them. ${ }^{78}$

\section{A Place for Feeling in the Life of the Law}

At a Conference on Educational Reform which I attended at Dartmouth College in the spring of 1967 , I was ungently dislodged from my complacent notions about teaching by students from all over the country who, as one of them has put it, "want to stop hearing' about being nice and start learning to be free." The pain, the rage, the frustration, the tears and the joy that were expressed during the three days of that conference, unrestrained by rules or agenda and uncon. taminated by politeness or deference, contrasted starkly with the emotional desiccation of my nicely managed classes. But more than anything else I was struck by the conspicuous omission of any reference to or concern about what was going on in the professional schools. The lack of interest, I was eventually informed, was based on the almost universal assumption that the professional schools-the law schools, in particular-were so far beyond the pale of redemption that it was futile even to talk about them. The feeling shared by many students was that law schools are places where old men in their twenties go to die. They were appalled by the incredible insensitivity of law schools to human needs, their monumental indifference to economic exploitation and social inequality, and their dedication to training ranks of law students to think like hired guns rather than to argue from personal conviction. The law school was seen as the deep-freeze of the emotional life of the university.

Neither the legal tradition nor the liberal temperament, which feeds a large part of contemporary legal theory, has ever been very hospitable to the life of feeling. Writing about liberalism in America, Lionel Trilling has called our attention to the paradoxical relation in which it stands to the emotions. ${ }^{77}$ While liberalism is theoretically "concerned with the emotions above all else, as proof of which the word happi-

76. Id. 130.

77. L. Trilling, The Liberal Imagination at $\times$ (1953). 
ness stands at the very center of its thought," Trilling writes, in its effort to carry out it political ends, "it drifts toward a denial of the emotions and the imagination."78

John Stuart Mill, during a period of emotional depression in his early twenties, became aware that the Benthamite ideal of human happiness held a negative and narrow view of human nature because, in its predilection for rational calculation, it had a tendency to impoverish the feelings and the imagination. As Wordsworth put it, "it murders to dissect."'79 Mill urged liberals to read Wordsworth and Coleridge, Trilling tells us, to recall them to the power of poetry. He wanted to remind them that imagination is "properly the joint possession of the emotions and the intellect, that it is fed by the emotions, and that without it the intellect withers and dies, that without it the mind cannot work and cannot properly conceive itself." 80

The polarization of "intellect" and "feeling" is etched in the development of the law itself. Nowhere is the conflict dramatized more forcefully than in the area of obscenity. ${ }^{81}$ Ideas about sex, the Supreme Court has said, like political or economic ideas, are constitutionally protected, no matter how offensive they may be to the moral sensibility of the community. ${ }^{\$ 2}$ The expression of sexual feelings, however-

78. Id. $\mathrm{x}, \mathrm{xi}$.

79. See 2 Introduction to Contearporary Civilization in the Wiest 440 (3d cd. 1954).

Mill wrote of this period in his life:

For I now saw, or thought I saw, what I had always before reccired with incredulity

-that the habit of analysis has a tendency to wear away the feelings: as indeed it has, when no other mental habit is cultivated, and the analysing spirit remains without its natural complements and correctives ... Analytic habits may thus even strengthen the associations between causes and effects, means and ends, but tend altogether to weaken those which are, to speak familiarly, a mere matter of feeling. They are therefore (I thought) favourable to prudence and clearsightedness, but a perpetual rom at the root both of the passions and of the virtues; and, above all, fearfully undermine all desires, and all pleasures .... My education, I thought, had failed to crcatc these feelings in sufficient strength to resist the dissolving influence of analysis, while the whole course of my intellectual cultivation had made precocious and premature analysis the inveterate habit of $\mathrm{my}$ mind ... . I had now leamt by experience that the passive susceptibilities needed to be cultivated as well as the active capacities, ... The cultivation of the feelings became one of the cardinal points in my ethical and philosophical creed.

J. MIIL, Autobiography 137-44 (1923) (emphasis added).

80. L. Trming, supra note 77, at xi. See J. Mill, ON Benthasi and Colendage 96-169 (1950).

81. See Finnis, "Reason and Passion": The Constitutional Dialectic of Free Specch and Obscenity, 116 U. PA. L. REv. 222 (1967).

82. Kingsley Int'T Pictures Corp. v. Regents, 360 U.S. 684 (1959):

What New York has done, therefore, is to prevent the exhibition of a motion picture because the picture advocates an idea-that adultery under certain circumstances may be proper behavior. Yet the First Amendment's basic guarantee is of frecdom to advocate ideas .... Its guarantee is not confined to the expression of ideas that are conventional or shared by a majority. It protects advocacy of the opinion that adultery may sometimes be proper, no less than advocacy of socialism or the single 
which is what "obscenity" is all about-is another matter. ${ }^{82}$ Unless it is redeemed by some "saving intellectual content," 84 the communication of erotic feelings is not entitled to the benefit of the First Amendment. Here, the life of the mind and the life of the body have been divorced and the latter evicted from the mansion of the law, left to pursue a career of its own in the underworld of erotica. The legal temperament, after many years, has finally become receptive to sex in the head, but is having much more difficulty with sex in the body as a viable human experience. "Polymorphous perversity" is crime in most jurisdictions ${ }^{85}$ and as Norman O. Brown has observed: "[I]f infantile sexuality, judged by the standard of normal adult sexuality, is perverse, by the same token normal adult sexuality, judged by the standitrd of infantile sexuality, is an unnatural restriction of the erotic potentialities of the human body." into a drama of evil in the house of the Law.

In the world of political discourse, speech that is exclusively emotive in its import-calling a police officer a "fascist pig" for example-has been disinherited by the law since it is "no essential part of any exposition of ideas." 87 The theoretical exposition of fascism, however, is protected.

The invidious constitutional distinctions between intellect and feelings, between the life of the mind and the life of the body, are rooted in the same dualism from which the traditional first amendment dichotomy between thoughts and acts spring. The expression of feelings is largely the language of the body; it is, in Kenneth Burke's phrase, "the language of symbolic action." 88 For example, I can talk about being angry without ever feeling angry. It is not until I clench my fist

tax. And in the realm of ideas it protects expression which is eloquent no less than that which is unconvincing.

360 U.S. at $688-689$ (emphasis added).

83. In Roth v. United States, 354 U.S. 476 (1957), the Supreme Court defincd "obscene" material as material dealing with sex in a manner appealing to "prurient interest" and defined "prurient" in part as "itching; longing; uneasy with desire or longing; of persons, having itching, morbid, or lastivious longings; ...." 354 U.S. at n.20 (emphasis added). Pornography is the expression, "distorted by repression, of the immortal desires of the human heart." N. BRown, LIFE Against DEATH 13 (1959). Cf. Sargent, W $d$ Poets, in E. SARGENT, LOVE POEMS (1966): "Everything we want is against the law."

84. Ginzburg v. United States, 383 U.S. 463,470 (1966).

85. See, e.g., CAL. PENAL Code \& 286 (anal intercourse); Cat. Penal Code \& 288a (oral intercourse).

86. N. Brown, LIFE AGANST DEATH 27 (1959).

87. Chaplinsky v. New Hampshire, 315 U.S. 568, 572 (1942). See People v. Cohen, 1 Cal. App. 3d 94, 81 Cal. Rptr. 503 (1969) ("Fuck the Draft'); Goldberg v. Regents of University of California, $248 \mathrm{Cal}$. App. 2d 867, 57 Cal. Rptr. 463 (Dist. Ct. App. 1967) ("Filthy Speech Movement"). Cf. Street v. New York, 394 U.S. 576 (1969).

88. K. BURRE, LANGuage as Symbolic Agtion (1966). 
and get in touch with the tightness in my jaw and the quivering in my stomach that I begin to experience real anger. ${ }^{89}$ Because the expression of emotion entails some motor activity of the body, it is closer to "action" than intellectual speech which purports to present us only with ideas for contemplation. The expression of feeling also entails making contact with the environment; in the case of anger, of contacting the object of one's rage. There is, then, in every emotive expression an element of assault. Indeed, among nonliterate peoples, "words play the part essentially of implements . . . . [and] are regarded as capable of doing things ...." Language, in its most primitive function is really "a mode of action rather than ... a countersign of thought." "o1

The extreme form of contact in the case of anger is homicide or the infliction of serious physical injury, which the law obviously must prohibit in the absence of justification or excuse. There are other modes of expressing emotion and making contact, horrever, that are not really dangerous, and constitute a vital part of human experience, but which are also forbidden. These include emotive language, certain forms of symbolic conduct, and the expression and gratification of sexual feelings. For some reason that is not entirely clear-perhaps (as I have suggested) because feelings mobilize the body to action while ideas presumably only stir our brains around a little-the law has persisted in treating the language of the body and the language of the mind as separate constitutional categories.

While there is no constitutional compulsion to adopt any particular theory of human behavior, we ought at least to be aware that the perpetuation in the law of this dualism confirms a fragmented and alienated vision of man. In its insistence upon the intellectualization of feeling as a condition of constitutional protection, the law denies what is most deeply human in us. In its effort to preserve the distinction between thought and acts, the law reduces human expression to an unending dress rehearsal for life.

The political implications of preserving the traditional distinctions are disturbing, if not entirely clear. Intellectual discourse alone, as Susan Sontag has pointed out, is itself a radical political strategy "for conserving an old text, which is thought too precious to repudiate by

89. See F. Peris, Gestalt Therapy Verbatm 64 (1969).

90. A. Montagu, The ANatomy of Swearinc 8 (1967).

91. Malinowski, The Problem of Meaning in Primitiv'e Languages, quoted in A. MroNtagU, The ANatomy of SwEaring 8 (1967). 
revamping it." must learn to see more, to hear more, to feel more." 33 In short, in politics, as in contemporary art, the demand is not for a change in ideational content but for a radically new aesthetics of expression."

\section{The Development of Creativity}

The explorer is totally inconsistent. He never knows at what moment he will make some startling discovery. And consistency is a meaningless term to apply to an explorer. If he wanted to be consistent, he would stay home.

-Marshall McLuhan ${ }^{95}$

We are desperately in need of room for feeling not only in the development of the law, but in the process of learning law as well. We need what Abraham Maslow calls "a healthy irrationality" with which to move beyond the limitations of purely abstract and logical modes of thought. ${ }^{96}$ Humanistic psychology has made us aware that it is the "ability of healthier people to dip into the unconscious and preconscious, to use and value their [feelings] . . . instead of fearing them, to accept their impulses instead of always controlling them, [that] turns out to be one of the main conditions of creativity." 07 Research and

92. S. SONTAG, Against INTERPRETATION ANd OTHER ESSAYs 6 (1966).

93. Id. 14.

94. The idea of speech as symbolic action has been most tendentiously expressed by Artaud:

We need true action, but without practical consequences . . . Theater, like specel, needs to be set free. This obstinacy in making characters talk about feclings, passions, desires, and impulses of a strictly psychological order, in which a single word is to compensate for innumerable gestures, is the reason ... the theater has lost its trut raison d'etre... . [Speech should be] called upon to address not only the mind but the senses, and through the senses to attain still richer and more fecund reglons of the sensibility at full tide ... [L]et there be the least return to the active, plastic, respiratory sources of language, let words be joined again to the physical motlons that gave them birth, and let the discursive, logical aspect of specch disappear beneath its affective, physical side ....

A. Artaud, The Theater and Its Double 115, 118-19 (1958) (emphasis added).

95. G. STERN, MCLuhan: HOT ANd Cool xiii (1967).

96. A. Maslow, Toward a Psychology of Being 208 (1968).

97. Id. 195. Cf. Fromm, Psychoanalysis and Zen Buddhism, in D. Suzuk1, E. Hwom \&

R. DeMartino, ZeN Buddhism \& Psychonnalysis 77, $101-02$ (1963):

The second aspect of the filter which makes awareness possible is the logic which directs the thinking of people in a given culture. Just as most people assume that their language is 'natural' and that other languages only use different words for the same things, they assume also that the rules which detcrmine proper thinking, are natural and universal ones; that which is illogical in one cultural system is illogical in any other, because it conflicts with natural logic. A good example of this is the difference between Aristotelian and paradoxical logic .... which assumes that $\Lambda$ and non-A do not exclude each other as predicates of X. Paradoxical logic was predominant in Chinese and Indian thinking, in Heraclitus' philosophy, and then again under the name of dialectics in the thought of Hegel and Marx. The generil prin. ciples of paradoxical logic have been clearly described in gencral terms by Lio.Tse: 
experimentation in "synectics" has demonstrated that in the development of creative potential, "the emotional component is more important than the intellectual, irrational more important than the rational."'98

In an age in which men have begun to explore outer space, a more fantastic space odyssey awaits us: an exploration of social space-between man and man-and a journey into inner space-between a man and his self. Only in an atmosphere of openness to the entire range and depth of human experience can creativity flourish. This means the learning process must include the sensory awareness, the playfulness, the imagination and the spontaneity of expression often associated with childhood. "[I]maginative creation," Freud wrote, "like daydreaming, is a continuation of and substitute for the play of childhood."99 Ironically, it is the non-sense of traditional education that lays waste the imagination of children and "turn[s] them into imbeciles like ourselves, with high [gradepoint averages] if possible."100

If, as Freud made clear, the creative potential resides largely in the unconscious, ${ }^{101}$ then the development of creativity will depend upon the extent to which we are successful in developing methods for making the unconscious accessible to ourselves and sharing our creations with others. These methods include intuition, metaphors, puns, myths, fantasies, daydreams, and hypnagogic experiences. ${ }^{102}$ Their productiveness, in turn, depends on an atmosphere in which an individual is encouraged to be irrelevant, to play, to be wrong, to take risks, to be inconsistent, to tolerate ambiguity and to express the ridiculous. Each of these roads to creativity has been traditionally regarded as anathema to the legal mind and is systematically dynamited in the classroom. If a student seeks to leave the conventional track and embark on an imag.

"Words that are strictly true seem to be paradoxical." And by Chuang-tzu: "That which is not-one, is also one...."

The third aspect of the filter, aside from language and logic, is the content of ex. periences. Every society excludes certain thoughts and feelings from being thought, felt, and expressed ....

We come, then, to the conclusion that consciousness and unconsciousness are socially conditioned. I am aware of all my feelings and thoughts which are permitted to penetrate the threefold filter of (socially conditioned) language, logic, and taboos (social character) ....

98. TW. Gordon, Srnectics 6 (1961).

99. Freud, The Poet and Day-Dreaming, in S. Freud, ON Crestritry ANd the UNCoNscious 52-3 (B. Nelson \& J. Riviere transl. 1958).

100. R. Laing, The Politics of Exrerience 58 (1967).

101. Freud, supra note 99 , at $44-54$.

102. On the hynogogic experience ("the state between waking and sleeping"), see Van Dusen, The Natural Depth in Man, in C. Rogers \& B. SteveNs, PersoN to PessoN: TuE Probleir of BeING HuMaN 211, 217-22 (1967). 
inative voyage of his own, the ridicule of a professor or his own fear of being thought "irrational" eventually edits the creativity out of his consciousness, and the student comes to learn that he must travel the course in the same train in which everyone else is riding. The journey out of the socially shaped compartments of our minds into the depths of our inner space is a terribly lonely experience, for it is a place where no one has ever been before. The frightening doubt is always there: "Perhaps I am foolish, or wrong, or lost, or abnormal."103

In seeking to develop "lawyering" skills, we have stubbornly restricted ourselves to the cultivation of "intellect" and have ignored the affective domain from which creativity springs. We believe either that creativity is something that cannot be learned in the schools or that it can be coaxed or forced, like a bowel movement from a reluctant child, and then enforced by the training of the Socratic method.

The Socratic dialectic, though, as John Herman Randall has pointed out, is not the discipline of symbolic logic, but rather "the imaginative experience of the artist"104 - a flight of the imagination through a world of allegories, parables and myths, a voyage through what has become a "lost continent" in our culture. To restore that vision, to return to the human and humanizing spirit of the dialogue in which the quest for knowledge is propelled not by fear but by eros, to return ourselves to our selves-and in that sense to begin to create a community in the classroom-is, perhaps, one way in which we can begin to make of legal education something more than a dreary task for a future payoff.

\section{An Experiment}

In a course entitled "The Family and the Law" this past year, a group of students and I attempted to break through the highly structured and controlled atmosphere of the traditional classroom. We experimented with several methods, including individual and group fantasy, rolcplaying, ${ }^{105}$ gameplaying, nonverbal communication and videotape feecl. back. There were thirty-four of us: twenty-nine men and five women. We met twice a week in two-hour sessions in a large, comfortable room with a fireplace, carpeting, bookcases and usually sat in a large circle

103. Rogers, Toward a Theory of Crealivity, in C. ROGERs, ON BECOMMNG A PEHSON 347,356 (1961).

104. Randall, Plato as the Philosopher of the Artistic Experience, 37 TIIE AMERICAN SCHOLAR 502, 509 (1968).

105. "Roleplaying" refers to the spontaneous acting out of a past, present or futurc situation, either in the actor's own experience or that of another person. Sé $\mathrm{R}$. CorsinI, Roleplaying in Psychotherapy (1966). See also J. Moreno, Psychodrana (1964). Moot court is the most familiar form of roleplaying in the law school. 
or several concentric circles. Spatial arrangements shifted with the needs of the group. We frequently broke down into small groups of five or six to facilitate personal interaction among group members. Students were encouraged to stay in the here-and-now and to put themselves into their statements-to talk in terms of " $I$ " or "me," rather than referring to what "people" think or "society" says; to roleplay cases involving attorneys and family members, rather than intellectualizing about what they "would do" in a hypothetical situation; to fantasize an observation or an idea, rather than trying to "reason it through;" and to tune-in to nonverbal messages by imitating the bodily positions of other members of the group and trying to experience the corresponding feelings.

Part of the group process was dialectical. For example, a student arguing a point might be asked to stvitch chairs with his adversary and to state as persuasively as possible the adversary's position. Or I might suggest that they continue communicating, but without using words, only sounds and gestures. That gets them to listen to the medium rather than the content of the communication and to see how the voice and the body can believe the verbal message. A sometimes sobering dialectical exercise that helps to break down excessive intellectualization and mobilize a student to explore the emotional underworld of his ideas is to ask him, first, to state and argue his position on a particular issue and then to suggest that he repeat each of his original assertions, this time adding after each one a statement like, "And that is a lie," or "That is a lot of crap." He is then asked to argue the opposite of his original position as emotionally and forcefully as possible. This may be done either in pairs or in larger groups; the important thing is to encourage each individual to experience the polarities within himself (rather than to polarize a debate between members of the group) by giving a voice to each part: the "conservative" part and the "radical" part; the "cynical" self and the "idealistic" self; the "parent" and the "child;" the "top-dog" and the "under-dog."100 If a student really gets into these opposing parts of himself, there is the possibility of achieving integration through arvareness and appreciation of the conflicting forces-which is the only kind of "synthesis" worth pursuing.

As Edgar Bodenheimer has pointed out, ${ }^{107}$ the dialectical method is

106. See generally, E. Shostrom, Man, tHe Manipulator (1968).

107. Bodenheimer, $A$ Neglected Theory of Legal Reasoning, 21 J. of LEc. ED. 373 (1969). 
widely used in the practice of law, yet its theoretical foundations and practical implications have been neglected both in the literature on the logic of the law and in legal education itself. What passes for dialectical discourse in the classroom is, at best, no more than a set of exercises in the application of deductive inference, inductive generalization and analogical reasoning. And much of the philosophical consideration of the dialectical process has been permeated by metaphysical assumptions about the existence of some inevitable process that will lend to the "right" or "just" result.

Most legal issues, like ethical conflicts, involve what Charles Steven* son calls "disagreements in beliefs" and "disagreements in attitude." 108 To the extent that legal arguments are based upon disagreements in belief-e.g., whether marijuana is addictive or has harmful effects; horv important confessions are to the successful prosecution of a criminal case; whether the death penalty has a deterrent effect-those conflicts can eventually be resolved by the methods of science and formal logic. But insofar as disagreement is based on disagreement in attitude-is freedom more important than security; is privacy to be preferred to safety; shall equality take precedence over freedom of association; is the honor of our nation more important than human life-to this extent, science and logic are irrelevant to the resolution of legal conflict. Behind every clash of values, there is a polarization of emotions and an implicit demand that your adversary share the feelings and attitudes that you experience with respect to a particular issue. "Absolute justice," then, as Kelsen has attempted to demonstrate, "is an irrational ideal." ${ }^{109}$ To put it another way, the contours of our legal norms are defined by the landscape of our emotional lives. "It is impossible to decide between ... two conflicting judgments of value in a rational scientific way," Kelsen writes. "It is, in the last instance, our will, and not our reason; the emotional, and not the rational element of our consciousness which decides this conflict."110

It is important, then, to provide a place for the life of feeling in legal education, not just because the sharing of feelings among teachers and students is a nice experience, but because, in the end, the process of lawmaking is determined by undercurrents of human existence far more subtle and profound than the shifting winds of doctrine or the ballast of empirical data. When students seek to penetrate the fortress

108. C. Stevenson, Facts and Values 1-9 (1963).

109. H. Kerson, What is Justice? 5 (1957).

110. Id. 21. 
of value judgments implicit in legal rules, they are left at the gatehouse with some bland cliches or what Jerome Frank used to call "weasel words" about "reasonableness" or the importance of "balancing" conflicting social interests. ${ }^{111}$ These are little more than bits of mystifying rhetoric that merely restate fundamental questions in a way designed to discourage the student from asking them again. Or else students are told that the function of the law is to enforce community standards or to secure the greatest "happiness" for the greatest number, which is nothing more than democratic propaganda or "liberal" politics masquerading as a legal definition or a definition of law. 112

I have no objection to propaganda in the classroom-students experience it every day in our schools except that we do not like to apply such a pejorative term to teaching American middle-class values; we generally reserve it for teaching values we do not like. ${ }^{113}$ What is important is that teachers make explicit their own value judgments instead of dressing them up in the guise of "rational" and "objective" standards-a bit of semantic sleight-of-hand that makes it so much more difficult for students to reject the teacher's vision of the world and make up their own minds about how the law should deal with social problems. It is through the dialectical process that the student can achieve his own personal synthesis, but it is only when the dialectic penetrates the intellectual layer and makes him aware of the opposing forces within himself that he will begin to experience a meaningful integration of ideas rather than a repetition of the old conflicts. "Internal" dialectical arguments (which constitute the dynamics of "reasoning" about values) are, in many ways, like dreams. The various parts and characters in the drama of the argument, like the bits and pieces of our dreams, represent parts of ourselves; the "antithesis" in the dialectic, like the "demons" and objects in our dreams often represent alienated parts of ourselves, the parts we have dis-owned. I have therefore taken as a basis for my approach to dialectical reasoning a theory of dreamwork that has been developed in gestalt therapy:

[T] ake each one of these different items, characters, and parts, and let them have encounters between them. Write a script. By 'write a script,' I mean have a dialogue between the two opposing parts and you will find-especially if you get the correct op-

111. J. Frank, LAw ANd the Modern MiNd 30 (1963).

112. C. STEVENSON, supra note 108, at 14-15.

113. See C. Stevenson, Ethics aNd Laiguage 243-52 (19:4). 
posites-that they always start out fighting each other. All the different parts-any part in the [internal argument] ... is yourself, is a projection of yourself, and if there are inconsistent sides, contradictory sides, and you use them to fight each other, you have the eternal conflict game, the self-torture game. As the process of encounter goes on, there is a mutual learning until we come to an understanding, and an appreciation of differences, until we come to a oneness and integration of the two opposing forces. Then the civil war is finished, and your energies are ready for your struggles with the world. ${ }^{114}$

The management of aggression in the classroom is another difficult problem that we have not really faced. Andrew Watson is of the opinion that "those who study law in the United States, as well as England, tend to have a greater than average need to deal with this force."110 And because it is so critical in the adversarial process, we need to pay more attention to it in the educational process. It is also important to get students in touch with their own aggressive impulses and to understand the therapeutic ${ }^{116}$ as well as the destructive uses of aggression before they consider the role of the law in regulating social disorder and violence. This is a point that is often overlooked. Students who are trained in an environment in which it is disruptive to write your name in the wrong place in an examination book and treasonable to challenge the authority of the professor are hardly likely to have a very sanguine view of civil disobedience or ghetto riots.

William Schutz ${ }^{117}$ and others ${ }^{118}$ have developed several methods for using space, movement and physical contact to get people more in touch with the feelings underlying their aggressive verbal behavior or to encourage quiet and passive individuals to express their aggression. These include simple exercises such as standing on a chair to experience the feeling of dominance in a group, thumb and arm-wrestling, pushing, breaking into or breaking out of a circle of people, and other forms of physical confrontation. The ancient Japanese martial art of Aikido, recently introduced here, ${ }^{119}$ in its emphasis upon integrating mind and body, has a provocative relevance to the teaching of dialectical and adversary skills. Most of the verbal aggression I have experienced in

114. F. PerLs, Gestalt Therapy Verbatiai 71 (1969).

115. Watson, The Quest for Professional Competence: Psychological Aspects of Legal Education, 37 U. CINN. L. REv. 93, 102 (1968).

116. See Coser, Some Social Functions of Violence, 364 Annuts 8 (1966).

117. W. SchuTz, JOY, ExPANDING HUMAN AWARENESS 125.26, 131-34, 156.73 (1967)

118. See, e.g., Selver, Report on Work in Sensory Awareness and Total Functioning, in Explorations in Humian Potentialtties 487 (H. Otto ed. 1966).

119. K. TOHEI, What is AIkIDO? (1962). 
the classroom and the courtroom involves the use of brute force to defeat an opponent, much the way in which physical strength is used in arm-wrestling; and, as in arm-wrestling, where the adversaries are equally matched, the combat results in enervating deadlock. Courtroom combat, I think, should be more like the art of Aikido, which is relatively effortless; you make your opponent come to you and then use his "own strength in leading [and throwing] him:"

Let your opponent go where he wants to go; let him return where he wants to return and bend in the direction he wants to bend as you lead him, and then let him fall where he wants to fall. There is no need to strain yourself unduly. ${ }^{120}$

Plaintiffs' attorneys, I suppose, will balk at this method of training, but for defendants' attorneys, I know of no better method of teaching the art of defense.

Another method that may be useful in helping students to get in touch with their aggression is to suggest that individuals experiment with new and extreme forms of responses. For example, a student who is usually timid and withdrawn might be encouraged to be aggressive (even to the point of obnoxiousness) during a particular class meeting; or a student who tends to dominate the discussions might try remaining silent or repeating what another student has said-that is, to give and get feedback-before responding to it, as a way of checking out the extent to which he is hearing what other people are saying.

Videotape was used extensively in the class as a method of providing students with feedback to gain greater awareness of themselves and insight into what was happening in the group. Simulated interviews with clients were televised by group members and played back so that students could see themselves as a client might perceive them in a real setting. ${ }^{121}$ Before getting into these simulated interviews, I suggested that we try a more personal, but relatively "safe" way of getting in touch with what it is like to be involved in a helping relationshipeither as a "helper" or as a person seeking help. The class had read Carl Rogers on "The Characteristics of a Helping Relationship,"122 but like everything else they read, it would remain a meaningless abstraction until they began to experience personally what Rogers was talking about. We broke down into four or five small groups, and each member

120. Id. 17.

121. See Ramey, Teaching Medical Students by Videolape Simulation, 43 J. Mrmical. Education 55 (1968).

122. Rogers, The Characteristics of a Helping Relationship, in C. Rocers, supra note 103 , at $39-57$ (1961). 
was asked to write (anonymously) on a slip of paper a personal problem with which he might go to a friend for advice. From these, a person from each group drew one of the problems and roleplayed a person seeking help with that problem; another group member played the role of the helping friend. The rest of the group observed the inter action and then provided the "helper" with feedback after the "inter" view" was terminated. Each encounter, including the group reaction, was recorded on videotape and played back immediately. This was, for many students, the most awakening experience of the class. Seeing themselves use facial expressions, body movements, gestures and tones of voice which they were unaware of during the interview and listening to other people react to what they regarded as "being helpful," students were startled, thoughtful, amused, sobered, gratified. A student was thereby given the opportunity to see the difference between the way he experienced himself and how others perceived him, and to consider the difference between the messages he intended to communicate in the interview and the messages that were actually received.

We used other "games" to simulate various types of interaction in a family system and thereby provide some experiential meaning to terms like "marital discord," "breakdown in communication," "irreconcilable differences," and to challenge students' common sense assumptions about "happy" and "normal" marriages as well as their theories about the "causes" of divorce. For example, a simple nonverbal game in which two people sit facing each other and silently trace the movements of each other's hands as if they were mirror images of each other can dramatically demonstrate for each pair how "power" is exercised in a relationship: who "leads" and who "follows;" how that decision is made and enforced; how the "follower" can ultimately control the relationship by allowing his mate to be the "leader." Other exercises can be devised to demonstrate the set of mental mirror images that determine the behavior of one person with respect to another: how I see me; how I see you; how I see you seeing me; how I see you seeing me seeing you. ${ }^{123} \mathrm{~A}$ failure of communication can take place on one or more of these levels. For example, Peter wants children but Mary does not (disagreement); or Peter and Mary both want children (agreement) but Peter mistakenly believes that Mary does not (misunderstanding); or Peter and Mary each know that the other wants children (uncler-

123. See R. Laing, H. Phillipson \& A. Lee, Interpersonal Perceition 143.74 (1966). 
standing) but Peter incorrectly assumes that Mary thinks he does not want children (failure to realize understanding). ${ }^{124}$

I have no way of measuring how much each student learned in the class. Our meetings were exciting, playful, boring, threatening, awakening, maddening, disappointing, joyous. At times, our sessions were more like improvisational theatre than class meetings. On other occasions, they were more like tiresome bull sessions. Almost all of us, though, came away from the experience feeling that something important had happened and, in some way, had changed each of us. In the end, I suspect that the techniques and games were secondary. Some of them proved to be very effective; others did not work very well for us. What was most important was a certain openness and authenticity that we came to share with each other and a willingness to risk the exploration of new experiences-to risk losing our heads in the hope of coming to our senses. ${ }^{125}$

\section{Of Grades and Growth}

Grades are the effluvia of the dying body of traditional education. That is not to say that evaluation serves no useful purpose in an academic institution. Without some kind of feedback, life, I suspect, would be intolerable for students as it would be for any living creature in any other environment. But the tendency to use grades as a disciplinary device or an incentive is useless, if not damaging, for it promotes no real growth. Where the educational environment has become a morgue, you cannot restore life by offering prizes for cadaver-of-theyear.

Moreover, we have a substantial body of evidence that supports the conclusion that "the relationship between course grades and occupational success is in fact very low, often approaching zero."128

I suspect that in one sense, we take grades too seriously, as if an overhaul of our grading system would solve all our problems. Changing grading systems, though, is like changing wives; our problems live after them.

The purpose of eliminating grades, I take it, is to remove the fear of not "doing well" so that students will have the courage to risk ex-

124. See id. 23-34.

125. See F. Perls, Gestalt Therapy Verbatm 50 (1969).

126. C. JeNchs \& D. RIEsMlan, The AGadenic Revolution 205 (1968). Sec also Raimi, Examinations and Grades in College, AAUP BuLLETIN, Autumn 1967, at 311. 
ploration of new areas in both the curricula landscape and in their own interiors. Creativity is discouraged by humiliation, criticism and punishment for failure. The student is taught that he "has to be more, better, in order to be somebody."127 We never think of telling him that he is good enough as he is. We can't because we don't even permit ourselves to believe that we are good enough as we are. We keep on rejecting what we are and then wonder why it is that we are living in a condition of "alienation."

One of the most important conditions of creativity, as Carl Rogers outlined them several years ago in a talk at a Conference on Creativity at Ohio State University, ${ }^{128}$ is that the locus of evaluation be internal: "Have I created something satisfying to me? Does it express a part of me-my feeling or my thought, my pain or my ecstacy?" These are the only questions, Rogers insisted, that really matter to the creative person. ${ }^{129}$

That doesn't mean that we should start pampering and indulging students or celebrating everything they do. But, there is a critical, if subtle, distinction between saying to a man, "I don't like your ideas" and "You are a $\mathrm{C}+$ student." There is an important difference between prodding a student to conform to some external standard of excellence and encouraging him to develop his own unique capacity for growth. Promoting creativity and growth then requires us to chart a caurse somewhere between the Scylla of reward and punishment and the Charybdis of protectiveness and indulgence. And somewhere along the line we ought to free ourselves from the nation that we are somehow responsible for whether or not students learn anything. That sense of responsibility has been spawned by the Victorian assumption that students are public charges delivered into our custody for the duration of their academic lives. As long as we insist upon being responsible for our students, they will never learn to be responsible for themselves. Frederick Perls is the author of a bit of wisdom on this subject that has come to be known as the Gestalt Prayer. I think it would be a liberating way in which to commence our classes:

I do my thing, and you do your thing.

I am not in this world to live up to your expectations

And you are not in this world to live up to mine.

127. Dreikurs, The Developing Self in Human Potentialities, in Human Porentuatities: The Challenge AND the Promise 80, 84 (H. Otto ed. 1968).

128. Rogers, Toward a Theory of Creativity, in C. ROCERs, supra note, 109, at 847. (1961).

129. Id. 354. 
You are you and I am I, And if by chance we find each other, it's beautiful. If not, it can't be helped. ${ }^{130}$

To return to the issue of grades, if we eliminate A's and B's and C's, but substitute some other method of forcing conformity to external standards (e.g., "Honors-Pass-Fail"), or if we perpetuate the professor as Authority and Judge, we only delude ourselves. If we are committed to retaining our present forms of education, then we cheat students by depriving them of grades; where the only incentive to learn is the grade, its removal will bring the entire engine of education to a complete standstill. Perhaps that would be beneficial. It seems, though, that those law schools which have experimented unsuccessfully with some variations of a "Pass-Fail" system have neglected the possibility that the failure may be in the educational organism itself and are now contemplating a return to the regular grading system rather than a re-examination of the entire structure of education. My own conviction is that unless we are prepared to go the latter route, we ought to stop entertaining ourselves with the illusion that we are doing something about facilitating real learning by tinkering with the grading system.

One method of feedback that I have found valuable both for myself (we sometimes forget about our orn needs) and for students is the Journal. Each student keeps a journal for the duration of the class and is encouraged to make whatever entries he wants, no matter how wild or irrelevant they might seem-fragments of ideas, speculations, feelings about himself or other persons in the class, fantasies, far-out theories, observations, resentments, reactions to a particular reading or to a class. The journals are turned in periodically. I read them, enter my own comments, share some of may feelings and impressions, and then return them. At the end of the quarter, each student has a collection of correspondence between the two of us and between him and his self. Here is an entry from one journal:

I really really like the idea of this journal! I think it should be encouraged in our culture .. . Girls can write in diaries but American males can't; it is very anti-John Wayne to express feelings-a strike against masculinity and all that. It is too bad because reading over what I have written was a real experience. I recognized myself.

The Journal is one way of beginning to open ourselves to our students

190. F. PERLS, supra note 125 , at 4. 
and themselves to us. Reading and writing in each of the journals was enormously time consuming; at times, it was maddening and discouraging to read what students had written, but it was also exciting and joy* ful. It was a beginning of talking person-to-person, and of collaborating in a joint and mutual evaluation, measured in terms of each individual's growth rather than his conformity to someone else's set of expectations.

\section{Three Entries, an Encounter, and a Poem}

1.

It doesn't seem like this class has been meeting for 10 weeks. But, when I look back over how I think this course has changed me, perhaps that length of time has expired. The sessions have given me great joy, as when I feel that I have finally said something that I understand and others do too . . . . I don't know how to clearly state what has bothered me throughout the course, but I have felt a threat of destruction of what I have been taught, and what I had believed to be true. This has given me pause to reconsider the effect of the law on individuals ... and the immediate application of some of our class experiences in my own life ... My gut feels good. 2.

[Family Law Journal Entry of V.]

I suppose the word that most closely represents my feelings is "disappointment." I was rather looking forward to this class for several reasons. Needless to say, I'm so fucking bored with law school, I can hardly see straight and I had hopes that this class would be a refreshing change of pace . . . . I'm afraid that I really didn't get any tremendous insight into "our group" and in fact, found almost all of the observations to be bullshit.

[Family Law Journal entry by $\mathrm{G}$ for October 10, 1968]

I suppose I could start out by saying that I'm really tired of writing in this book, but I guess that wouldn't be fair . . . . I could tell you about all the wonderful things that have happened to me. . . (Monday's class was fantastic and if you remember I participated a great deal that night even to the point of cutting $X$ off when he started one of his long dissertations) .... and all the new things that have opened for me, but the fact of the matter is that I'm not quite sure how this course has affected me. I have given a lot of thought to what I saw and felt during the last ten weeks and I think we only scratched the surface, but, at last, we have begun.... 3.

[Family Law Journal entry by G for December 15, 1968]

I'm in my brother-in-law's room, listening to his records. I often seek this refuge when we visit my wife's folks. Especially when I'm like this; so filled with strange churnings .... I went to the prison 
last night and it happened again: I soaked up much electric anguish; I felt the currents beneath the words and faces. Now I'm here and expected to communicate in the old way-I can't. So I'll play some records.

The convicts are responsive to Johnny Cash, but quiet, as the Okie band grinds out another tune. Then the deep, nasal, twanging voice reaches:

$$
\begin{aligned}
& \text {... but Aahy shot a mahnn } \\
& \text { in Reenoo, jest to watch him } \\
& \text { daahyee... }
\end{aligned}
$$

and the hall at Folsom Prison erupts. Screams, applause, whistles, shouts of approval.

I remember the first time I heard the album I asked: "Shit! What kind of people are these convicts!" Now I know.

About the third time I went down to the prison I learned a lot about fear and what it takes to overcome it. I'd rapped with that convict before. We almost had something going, but he kept trying to give me a pitch. So I reacted and the words kept going while the communication stopped flowing. Now he's on the "hot seat" [in an encounter session] and he's talking about his achievements. He says he's straightening out. Learning to talk to squarejohns, losing the convict habit. I jump up; I tell him I dig our talks but that he makes me feel like I'm being hawked. Honest! I'm honest! I told him for him. I want him to be honest for him. The convicts are sullen, low boos are given. He reacts, gets hard. Well, fuck 'em. If I can't be honest, I'll never get to know anything, neither will they. Wait a minute ... what's going on? The talking's over, they're going to show a movie, the lights are out.

Son of a bitch I'm scared! I shouldn't have said what I did. I should have let him think he was selling me .... No telling how these guys will act in the dark if they hate you. They're not rational, not like us .... .

Jesus ... what's got into me?

I get up. Work my way in the dark over to where he's sitting. We rap. Get some coffee. ... I have one cigarette left. He offers me one of his non-filter prison butts. Our eyes meet ... it's good. "Tell you what," I say, "I'll trade you this Marlboro for one of yours." 4.

[Criminal Law Journal entry by J.]

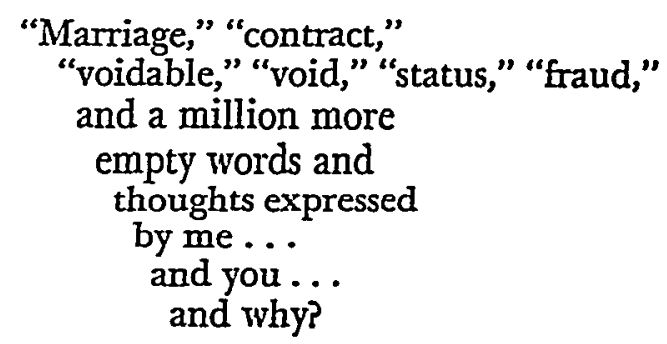


Bècause we're hére

$\ldots$ and have to?

find the word to

fill an empty space in time?

***

The room has slotwly filled with smoke and my eyes burn and it is hard to "see". . .

Gently floating clouds

distort the words that I perceive as I strive to focus

on

a group

That tries so hard to focus

Or,

the minds of twenty-nine.

is that the scene at all?

Perhaps my eyes and mind

are searching for

a thing that isn't there ....,

listening for some

different drum

that beats a silent plea

for something more,

While life goes on

and satisfies

the minds of twenty-eight.

[Family Law Journal entry by D.]

\section{Structure, Process and Space: The Politics of the Classroom}

Mr. T-, how do you reconcile your teaching of democracy with the way you conduct this class?

-An anonymous student.

\section{Structure and Process}

The classroom is not just a place where teachers and students meet periodically. It is a complex social and political structure. In so far as the learning experience of a student occur's in a class, his learning is a function of a process of social interaction and is defined in part by the power to determine the shape and content of the learning experiences of group members and how that power is exercised. In his interaction with the professor and other members of the class, the 
student will learn more about power, authority, justice, democratic living, freedom, aggression and intimacy than he will absorb from all the cases and books that he will read in his three years of law school. The process of education, then, is more important than its content; what you do in your classroom is more important than what you say. In short, the educational medium is the real teaching message.

The dialogue in the classroom is often misleading. What appears to be an argument about strict liability or contributory negligence may really be a struggle for power and respect. A particularly incisive rebuttal by the professor may be less important as instruction in torts than it is about getting straight who makes the rules in the classroom and what the penalties are for their infraction. Conversely, when a student asks a series of irrelevant or irritating questions, he may not be pursuing a new line of inquiry but implicitly asking, "Who's in charge here?" or "How far can I go before the professor will put his foot down?" Sometimes, a question directed toward eliciting the teacher's point of view is contrived more to ascertain the limits of permissible inquiry, Thus, a question such as, "Do you think the police generally conform to the requirements of law?" may be rendered more intelligible if understood as an effort to determine how safe it is in this class to criticize the police. In an argument with a student, a reference by a teacher to his prior experience as an attorney may serve a useful function as a bridge between theory and practice, but it also may be a method of confirming his authority in the classroom and invalidating the perceptions of the student. The implicit message may be: "Since you have never practiced, you are in no position to have an opinion." A set of rules prescribed by the teacher for analyzing certain types of cases may furnish the student with a useful model for problem-solving, which he is free to accept or reject, but more often it is intended and understood as another chapter in the Student's Practical Guide to Making It in the Law School Wrorld. In the jargon of the law school underrvorld, "Either you give the Man what he wants or he'll fail your ass out of the course."131

Thus as a student becomes initiated into the social life of a classroom group, he learns how power is distributed and exercised in the class (constitutional law); when and where to respond to the teacher and how to formulate his responses (civil procedure and evidence);

131. J. Farber, supra note 5, at 1 . At least one guide to the grading system-N. Stcrling, Memo on Grades, October 1969 (unpublished document on file in Yale Lav Library) -has been prepared for law students. 
the mutual expectations of teacher and student (contracts); the sanctions for violating the rules (criminal law); the limits of dissent (constitutional law); how to secure affection and approval from the teacher and the consequences of loss of love (family law); the boundaries of permissible expression of self (property); and how disciplinary measures can be perceived as ultimately benign, i.e., "for the student's own good" (juvenile justice). ${ }^{132}$ The efforts of many law schools to protect themselves from charges of discrimination in grading by assigning numbers to students so that the grading process remains anonymous provide a valuable lesson in justice. In their single-minded devotion to the principle of "fairness," the schools move imperceptibly toward a dehumanization of the educational process. "Justice," the student learns, is the uniform application of a single set of standards or rules, and he is gradually foreclosed from considering and experiencing the possibilities of a concept of justice based on authenticity, feeling, individual self-actualization and face-to-face encounter. ${ }^{133}$ He receives neither a humane education nor education in humane lawmaking.

The student, in effect, is learning about rules that govern behavior of people in groups which, after all, is what the law is about. When he has forgotten the Rule Against Perpetuities, the Statute of Frauds and the Doctrine of Collateral Estoppel, he will remember the rules that were responsible for the management of his experience as a law student, and while he may not be able to articulate them as such, the odds are that he will apply them to the regulation of his professional life with the same conviction and lack of awareness with which his mentors impressed them upon him.

Most conventional classrooms are autocratic in their political structure. There are basically two kinds of autocracies: the "tough" autocracy and the "benevolent" autocracy. ${ }^{134}$ The tough autocrat runs his class with a maximum of discipline, order, control and criticism. The professor is usually very conscious of his own position and authority and any effort to challenge it is swiftly suppressed. He believes that students cannot be trusted to learn without supervision and he is careful not to spoil students by lavishing too much praise on them. The benevolent autocrat, in contrast, is seldom harsh or severe; he

132. Power is always exercised by the faculty "for the best interest" of the studenty. Cf. In re People of the State of California, for the Best Interest and Protection of Morris Carley, An alleged narcotic drug addict, 81 Cal. Rptr. 414 (Ct. App. 1969).

139. See J. SHKLAR, LEGALISM 57 (1964); G. COHN, ExISTENTIALISM AND LEGAL SCIENGE 122-23 (G. Kendal transl. 1967).

134. National Training Laboratories, human forces in teaching and lisknino Series, No. 2, LEADERSHIP IN ACTION 53 (1961). 
provides as much praise as criticism; he seems as fair and is extremely helpful. What makes his classroom autocratic is his use of benevolence and praise as a method of manipulating students to conform to his own expectations and to foster dependence on him for direction and control of the class. In both types of autocracies, the role of the teacher is that of expert and authority. ${ }^{135} \mathrm{He}$ defines and presents the problems, indicates the correct method for solving them and checks the student's work for proper application of the method. The student has little or nothing to say about what he will read, how much he will read, when he will read it, what will be discussed in class today, how he will be evaluated, how many papers he will write and what he will write about. In some cases, the teacher may even tell him what size paper to use and where to set the margins on his typewriter. ${ }^{136}$ The amazing thing is that students stand for this. Conformity is exacted, I suppose, because a student's preceding sixteen years of education have taught him to be compliant, dependent, respectful and obedient. Most students really believe that the in loco parentis rules and regulations to which they are subjected are administered for their own benefit and that compliance is the road to professional success.

We deliberately and systematically create an environment in which autonomy is discouraged; where there is little opportunity for students to make decisions that affect their lives; where risk-taking is discouraged; where their only incentive to learn is reward and punishment; where they become exquisitely insensitive to each other and eventually to themselves. We then wonder why it is that practicing lawyers complain about law graduates not having any "common sense"-a congenial way of saying that our students lack judgment, autonomy, perception, the ability to make decisions on their own, to know how to deal with people, when and how to take the initiative, when to assume responsibility and when to pass the buck. I say that this is a "congenial" form of criticism because it assumes (falsely, I believe) that "common sense" cannot be learned in the schools, that it must await the experience of actual practice. It lets us return to our classrooms, aware of the profound inadequacies of our educational process, but content with the bland reassurance that we can't do any-

135. Even the "progressive" Model Code for Student Rights, Rcsponsibilities and Conduct, drafted by a committee of the American Bar Association, adheres to the concept of the professor as "the ultimate authority in the classioom." Comments, $\$ 5$, reprinted in STUdeNT Protest and the LAw 347 (G. Holmes ed. 1969).

136. See J. Farber, supra note 5, at 1 . 
thing about it and grateful for the bouquet from the Bar Asociation for the good job we're doing anyway.

What troubles me more than the absence of opportunities to learn valuable professional skills is the presence of forces in our law schools that tend to confirm or produce certain personality traits that are basically inimical to democratic values. Submissiveness to authority, dependence on external judgment, contempt for idiosyncracy, clistrust of feelings, excessive control of impulses, a predilection for formalism, and an intolerance for ambiguity - these are some of the qualities that are fostered by our traditional forms of legal education which are also found in the authoritarian personality. ${ }^{137}$

Max Weber, while he was concerned primarily with German lawyerdom, found at the heart of the legal ethos an inevitable hostility not only to all radical social reform but to democracy in general..$^{198} \mathrm{De}$ Tocqueville, while he was more sanguine about the compatibility of the legal tradition and democratic government, observed that American lawyers "secretly oppose their aristocratic propensities to . . . [the] democratic instincts [of the people] ...."130 And in a recent study of the personality of German lawyers, Walter Weyrauch has said of both American and German lawyers today that "contrary to common beliefs and formal resolutions, [they] may have personality traits that counteract or retard a wide distribution of democratic values among all persons." ${ }^{140}$

As the Supreme Court has noted, "a school is not like a hospital or a jail enclosure,"141 but there are so many striking parallels between educational institutions and what Erving Goffman has called "total institutions," such as jails, penitentiaries and mental hospitals, that their common characteristics ought to alert us to the dangers of

137. Gf. T. Adorno, E. Frenkel-Brunswick, D. Levinson \& N. Sanford, TuE Au* ThORÍtARIAN PERSONAITTY (1950).

138. See J. SHkLAR, supra note 133, at 16, citing M. WEBER, LAW IN ECONONY AND Socrety (M. Rheinstein ed. \& E. Shils \& M. Rheinstein transl. 1951).

139. A. DE Toquevilie, Dentocracy in AMERICa 175 (H. Commager ed. 1947).

140. W. WeYrauch, ThE Personactry of LawYers 279 (1961). "They lean toward non. equalitarian outlooks, at least on the unconscious level, preferring power and authority to persuasion." $I d$. Professor Weyrauch cites an unpublished study of American lati students which tentatively concluded that third-year law students who were "politically oriented" showed authoritarian personality characteristics. The study left open the possibility that these traits were acquired as a result of their legal education. C. Agger \& M. Goldstein, Law Students and Politics: The Rising Elite, 1957, (unpublished piper, on file in University of North Carolina Law Library).

141. Tinker v. Des Moines Independent Community School District, 993 U.S. 508, n.6 (1969), citing Hammond v. South Carolina State College, 272 F. Supp. 917 (D.C.D.S.C. 1967). 
perpetuating schools in their present form. A colleague of mine $e^{142}$ has pointed out some of the similarities between Goffman's description of the procedures of total institutions and the first year of law school. In the following excerpts from Asylums, I have substituted for such words as "inmates" and "patients" the word "student" and for the term "staff," the word "teacher":

Admission procedures and obedience tests may be elaborated into a form of initiation that has been called "the welcome," where professors or students, or both, go out of their way to give the new student a clear notion of his plight. ${ }^{1 / 3}$

$$
\text { *** }
$$

In total institutions there is a basic split between a large managed group, conveniently called students, and a small supervisory staff called faculty. . . . Each grouping tends to conceive of the other in terms of narrow hostile stereotypes, teachers often seeing students as bitter, secretive, and untrustworthy, while students often see teachers as condescending, highhanded, and mean. Teachers tend to feel superior and righteous; students tend, in some ways at least, to feel inferior, weak, blameworthy, and guilty. ${ }^{144}$

The Student comes into the establishment with a conception of himsself made possible by certain stable social arrangements [and modes of thought in schools previously attended]. Upon entrance, he is immediately stripped of the support provided by these arrangements. In the accurate language of some of our oldest total institutions, he begins a series of abasements, degradations, humiliations, and profanations of self. His self is systematically, often unintentionally, mortified. $\mathrm{He}$ begins some radical shifts in his moral career [italics in original], a career composed of the progressive changes that accur in the beliefs that he has concerning himself. . . . 145

Many [schools], like progressive mental hospitals, merchant ships, TB sanitaria, and brainwashing camps, offer the student an opportunity to live up to a model of conduct that is at once ideal and staff-sponsored-a model felt by its advocates to be in the best interest of the very persons to whom it is applied.140

142. Dov Grunschlag, Assistant Professor of Law, University of California at Davis.

143. E. Gofmsan, Asyluals, Essays on the Social Situation of Mentar. Patiento and OTHER INMATES 18 (196̣l),

144. Id. 7.

145. Id. 14.

146. Id. 64 . 
The alignments that have been mentioned represent coherent courses to pursue, but few students seem to pursue any one of them very far. In most schools most students take the tack of what some of the students call "playing it cool." This involves a somewhat opportunistic combination of secondary adjustments, conversion, colonization and loyalty to the student group, so that the student will have a maximum chance, in the particular circumstances, of eventually getting out physically and psychologically undamaged. ${ }^{147}$

The very methods we use in the classroom "undermine our chances of surviving as a viable, democratic society." This is the unsettling message of a recent attack upon American educational institutions by two college professors in a book entitled, Teaching as a Subversive Activity. ${ }^{148}$ Teaching civil rights to law students who are still treated as disenfranchised minority living in an academic Lowndes County ${ }^{140}$ or rhapsodizing about the value of freedom or privacy or due process in a setting in which students are not free to read what they want (at least not without running the risk of failing their courses) or sny what they really feel; where the only privacy they can find in the law school building is in the men's room, and where there is no appeal from the professor's final judgment of their academic performance, is like celebrating life in a mortuary. Our words fall on clead ears. We cling to the myth that we teach in ideologically neutral institutions, but as Robert Wolff has pointed out, while this may be true as far as the content of education is concerned, "the form of the education defeats content, no matter how radical. Theory is divorced from practice, students grub for grades in courses on revolution [and poverty] as eagerly as in courses on [corporations, federal income taxation and estate planning] . . . . Competition sets students against one another even in courses devoted to the study of cooperation and community." 150

In a course that $I$ am teaching this quarter on censorship and the law, I found it worthwhile to spend the first few hours just getting the class in touch with how we censor ourselves in group discussions and to understand what the pay-off is in holding back on self expres-

147. Id. 64-5.

148. N. Postaran \& C. Weingartner, Teaching as a Subversive Agtivity 15 (1969).

149. J. Farber, supra note 5 , at 1 .

150. Wolf, The Ideal of the University, Ghange in Higher Eduantion, SeptemberOctober 1969, at 48, 59 . 
sion; that is, to make explicit the self-imposed rules that inhibit freedom of expression in the classroom before proceeding to examine the function and social value of censorship in our culture. It is my conviction that without awareness of the processes that go in the midst of our classrooms, talk about democratic values and social policy is just so much crap.

It seems to me that the only kind of education that alone can claim to teach lawyers to function in a democratic society is education that itself is democratic and humane. In a democratic environment, students would share with teachers the decision-making about courses, assignments, scheduling, examinations, evaluation, and the content and structure of class meetings. It would require teachers to be Authorities less and people more-to give up control of the class, to cut out some of the phoniness and start to be more real. This is not an agenda for tomorrow or even the day after tomorrow, nor do I really think of it as a program. My thoughts are too fragmented, disconnected and illogical to fit into the contours of a proposal or recommendation. All I can do at this point is to share some of the impressions and feelings that have accumulated from my orn experience.

\section{From Forty-nine Fragments}

1. Nobody ever really learns anything that he has no interest in. Of course, a student can be forced to regurgitate certain things on an examination, but as I have been reminded recently, ${ }^{151}$ since examinations and toilets are the only places in our society where puking is permitted, regurgitative mastery has limited social or intellectual value. We ought to follow John Holt's suggestion ${ }^{162}$ and find out how much students forget after an examination and then take it all and throw it out of the curriculum, for that is what students do with it when the course is over; they throw it out after they throw it up. Then, we ought to take a look at the little they retain-what they make an integral part of their lives-and then try to understand what miraculous process produced this microscopic learning.

3. Students need freedom, not just because freedom is a nice thing to have, but because without space in which to breathe and grow, organisms wither and die. The trouble is that, basically, we don't trust students. We're afraid that if we give a student his head, he'll lose his mind or go to sleep in the cornfields. We seem to have lost

151. F. Perls, Gestalt Therapy Verbatnc 32 (1969).

152. J. Holt, How Cimbden FaII 175 (1964). 
sight of the fact that by maintaining a high degree of control and encouraging dependence on authority, we debilitate judgment, autonomy, the ability to deal with conflict and other qualities that a man or woman will need to cope with human problems in his or her professional life.

4. As I was writing the last paragraph, I almost omitted the women. We tend to forget about them in the law school, except to use them as foils for dumb jokes. Their perceptions are discounted unless they conform to our monolithic male vision, and there is no space for them to grow as women as well as lawyers.163 Our image of them is perverse: they come to be viewed as male attorneys in drag. In the course in "The Family and the Law" that I have previously described, ${ }^{154}$ without the women there to shake the male students loose from the myths with which most of them nourished their views of sexuality, love and marriage, the course would have been a collective delusion.

9. Educators like to talk about cultivating the intellect-a subject which chills me just a little because, I suspect, of my aversion to gardening in other people's minds. But, if we are really serious about nourishing growth, we must have forests, not deserts. As for "discipline" and "order," it is enough that the students do not run into the trees. 105

14. Students are not easily deceived, at least not after the first year of law school. By then, most of them are wise to our games, our pretenses, our vulnerability; except, they usually play "dumb" and don't let on that they know as much as they do, or else they deny what their instincts tell them about their education and they continue to play the game with implacable seriousness, so that the school becomes a place where students end up by rejecting their own intelligence. I have come to feel that I cannot teach without being honest about myself-my fears, my uncertainties, my boredom, my resentments. But that is not an easy thing to do; it is frightening and painful. Pain, though, seems to be one of those indispensable conditions of learning, and courage I think cannot come without the acknowledg. ment of fear.

15. Another word about honesty. If there are things we do not want to do or subjects that bore us-if we do not want to explore

153. See Kass, A Woman's View of Law School, 15 Student LAwYer J. 4 (1969).

154. See p. 468 supra.

155. See the dialogue in Marin, The Open Truth and Fiery Vehemence of Youth, Center Magazine, February 1969, at 68. 
certain lines of inquiry or examine certain problems or teach certain courses, we ought at least to be honest with students. Instead of telling them that these things are "unimportant" or have little "value" for lawyers or are not "appropriate" concerns of a law school, let us admit that they hold no interest for us or that we don't want to teach them or that they do not fit the contours of our own visions of what the law is about. Then, at least, students will be free to make their own judgments about the role of law and lawyers and decide for themselves what is important to them.

23. Learning is nothing if it is not an adventure. And I find in my own teaching that unless the journey is adventurous for me as well-unless I am learning myself-nothing very much happens in my classes. It is not enough for me to lead expeditions of students to places I explored last year; it is important that our journies be joint ad-ventures now.

29. Socratic "discussions" in which the professor attempts to get students to arrive at positions plotted by him in advance are not discussions. They are lectures or recitations masquerading as discussions. Lectures, when they are informal, open-ended, invite questions and comments, and are prepared to travel where students wiant to explore, can be exciting discussions.

30. I have been informed on numerous occasions that the printing press made the lecture obsolete, that anything that can be commucated in a lecture can more efficiently be transmitted to students in the form of printed copies of the text. MicLuhan I think has demonstrated the fallacy: "The auditory sense, unlike the cool and neutral eye, is hyper-esthetic and delicate and all-inclusive."160 Print-oriented media, he explains, endow men "with the means of repressing their feelings and emotions ..."157 When lectures take for their text the responses and questions of students-that is, when they generate an electric current between teacher and student and student and student-they serve to integrate the intellect and the senses.

31. To the extent that our educational forms are dominated by the printed text-and this accounts for ninety-nine percent of the present process of learning law-the law book publishing companies are more instrumental in shaping educational policy than all the curriculum committees and official bodies that pretend to have some impact on learning in our schools. I once estimated that if law students

156. M. MaLuhan, Understanding Media 86 (1964).

157. Id. 
were to pool the money they spend on casebooks over a period of three years into a single fund, we would have in a school of three hundred students over half a million dollars with which to produce the educational materials we need. That would mean that we could have what we need to teach rather than having to teach what we can get from the publishing companies. Each year we suffer the same bland fare from West, Foundation Press and Little, Brown \& Co., spiced with a few new cases and some stylish snippets from the latest law journals and commission reports to maintain the illusion of relevance. Each law school should have its own multi-media facility and staff equipped to produce the learning instruments we need in our classes: case files, trial transcripts, briefs, documents, photographs, maps, charts, videotapes and films of trials, client interviews, negotiations, arbitration proceedings, legislative hearings, soundtape and videotape recordings made by students and teachers engaged in field work including interviews, police radio motor patrol, community organization meetings, prison visits, in addition to the judicial opinions, statutes and law review articles which presently constitute the bulk of our resources.

34. I have heard teachers tell students that it is unrealistic for them to expect most of their classes to be exciting because much of their professional lives will be spent in doing things they do not like; and, since school ought to be a preparation for life, they might as well start getting used to that now. In trying to respond to that potent bit of logic, I never know where to begin: it sounds so convincing. It seems to me, first of all, that education is no more a preparation for life than today is a preparation for tomorrow. Of course, some people live for tomorrow, but I don't regard that as living. Secondly, in so far as school is a preparation for life, dull schools become places where people learn to live dull lives. You have only to watch a young child at play to understand that dullness is not instinctive; it takes years of learning and training to acquire it. And once acquired, the habit of dullness is rarely unlearned. Finally, the admonition to empty my life today so that I can prepare for the bleakness of tomorrow is neither a philosophy of life nor of education; it is the counsel of despair.

37. If we view the classroom as an ecological system, rather than an arena for individual performances, some things begin to make more sense. Consider grades for example. In a class in which there is a high degree of dependence of student on teacher and teacher on student for mutual confirmation, the need of the teacher to feel superior may be maintained at the cost of the students (or some number of the students) feeling worthless. Where students fail to conform to expecta- 
tions of the teacher, he may seek to maintain his position of authority by giving nonconforming students low grades. The individual student experiences pressure of the most powerful, though subtle, kind to conform to the rules that govern the social system in a particular class, and he may find that the only way he can effectively resist the pressure is to withdraw from the field of forces operative in the system. However, unless the student drops out of the class, the rules prohibit withdrawal and his defensive strategy is interpreted as academic failure. Whether a low or failing grade is actually a healthy response to a dysfunctional learning system, then, seems to me to be always an open question. Similarly, boredom in the classroom may be a political act, rather than a condition inherent in the individual student. That is, boredom may be a reaction to power, when the consequences of submission to authority are perceived as being too damaging to the individual. In attempting to understand the dynamics of the educational process, we might start paying more attention to entire systems of learning rather than isolated performances.

49. Whatever happens in my classes, I try to make the rules explicit and get students to become more aware of the group process itself. No school that I know of offers a course in "The Politics of the Classroom," but it is probably the single most important learning experience in the career of a student. To the extent that our law schools are engaged in the education of persons who will eventually play a significant role in making laws for other people, it is important that they understand first the laws that are made for them and the rules they impose upon themselves. We may not be able to dispense with laws, but at least we should be able to recognize them where they operate and decide how effective they are in encouraging the development of human potential and facilitating personal growth. Until lawmakers start understanding the nature of the rules they make for themselves that stifle their orm growth and impoverish their lives, they will never stop making laws that confine and deform the lives of other people. ${ }^{16 s}$

\section{Man in Space: The Architecture of Education}

Architecture, Frank Lloyd Wright once wrote, is form in space appropriate to man. ${ }^{159} \mathrm{It}$ is an arrangement of physical space that proceeds from the structure of our interior lives (inner space) and the dynamics of our relationships to other lives (social space). Buildings, then,

158. I am indebted to Ruth Saroy for this perception about law and lawjers.

159. F. WRight, AN ANIERICAN ARchitecture 19 (E. Kaufmann cd. 1955). 
are not merely containers for our bodies, but integral parts of our psychological and social lives. ${ }^{160}$

The pressing task is to create new environments for new kinds of learning experiences. We are concerned here not merely with benutification campaigns for our schools, but with generating a condition of education that is indispensable to learning itself. In reassessing the limits of inner and outer space, we might begin with the ecology of the classroom. Educational microspace-the distance between students and students and teachers and students-and their spatial organization in the classroom has remained essentially unaltered since the Rennissance. Students sit in (generally uncomfortable) chairs, neatly aligned in long rows (and frequently riveted to the floor), facing the teacher (never each other, on the theory, I suppose, that students never know anything worth hearing anyway). Visually, the classroom, as McLuhan has pointed out, is the exact counterpart of the linear structure of the printed page, "with the teacher like the page heading, and the lines underneath . . . the movable type being the students."101

\section{The Teacher}

stands at the head of the classroom, physically separated and isolated from students, like the heading on a printed page, although McLuhan's analogy is not quite precise since students in the classroom, unlike type, are not movable; interchangeable, perhaps, but not movable. The structure of the classroom determines its process: teacher centered, linear (one dimensional), static and detached. We can begin to crack the old educational molds by restructuring the visual, auditory and tactile environments, by opening up the space within the school and making it more flexible, enabling it to grow as educational methods develop.

We know from recent studies on the emotional and expressive values of direct visual contact, for example, that there is a significant relationship between classroom seating arrangement and active participation of students in the learning process. ${ }^{162}$ Rearranging straight rows of chairs around a table increases group interaction; a circular table is more effective than a rectangular table and a circular seating arrangement without a table is most effective in facilitating participation. The circular design also dislodges the teacher from his unique spatial loci*

160. See MaLuhaN, supra note 156, at 123-130.

161. McLuhan, $i$ wonder whether the rebellion of children . . . . in McLuinN, Hor \& Cool 145 (Stearn èd. 1967).

162. See Sommer, Classroom Ecology, 3 J. OF Applifd Beinviokal Science 489 (1967). 
tion in the classroom and closes the distance between teacher and student, between teaching and learning.

In large classes of say forty or more students, small group teachinglearning can be effectively combined with more conventional large group presentations by providing open and flexible classroom area that can be easily subdivided by partitions and by furnishing them with light, movable and "compressible" chairs and desks. This would enable a class during a single two hour meeting (for example) to move easily in and out of small and large group experiences. The same result could be accomplished, although with less intimacy for small groups, by simply altering the acoustical properties of a large unpartitioned area. In traditional schools, the large classroom is planned to facilitate voice projection over large distances, a design which makes it impossible for small groups to carry on simultaneous discussions. By using carpeting, porous ceiling materials and "wells" in the floors, however, the noise in the room can be maintained at a level that will permit this kind of teaching process. ${ }^{163}$ For large group activities, voice projection can be facilitated electronically by means of small, portable voice amplification units. By integrating these flexible open spaces with audio-visual systems and closed-circuit television networks, moot courtrooms and interviewing offices furnished with one-way mirrors and adjacent viewing rooms, the law school can begin to simulate the experiences and environments in which students will be immersed in their professional lives. Their education can be a living experience now.

Several elementary and secondary schools have been recently completed using the divisible open space concept, but not enough to standardize problems and render solutions commonplace. ${ }^{108}$ It has been described by one architectural journal as "an experimental but continuingly successful [architectural approach] countered by a complexity of newly engendered teacher-student relationships, ... [ the success of which will depend on] teacher response and student conditioning to this radical change in the traditional school space."105

In one of his occasional Sunday morning talks to the architecture students of the Taliesen Fellowship, Frank Lloyd Wright began with a tray full of seashells and inviting his students to "look carefully at these hundreds of beautiful, infinitely various little houses," he urged

163. See Site and Program Generate a New School Shape, Archirzcturar Rzcond, MIay 1969, at 138; Feedback on Three Schools, Progressive Architecture, March 1969, at 134, 142.

164. Id. 134.

165. Id. 142. 
them to seek in the design of their own structures that same "expression of inner life by appropriate form" manifest in the dwellings of these sea creatures. ${ }^{166}$ To judge from the buildings that house most of our law schools, they were designed with a monumental indifference to the inner needs of the human beings who come to live within its walls. The newer ones usually look like corrugated boxes, prisons or concrete appliances, rarely like human forms; but the saddest part is that nobody really seems to care much; the feeling is that almost anything with classrooms, faculty offices, a library and a toilet will do. In the construction of most school buildings, there is usually more politics than inspiration, more concern for efficiency than comfort or beauty. If education, though, is to be what Jacques Maritain called "a liuman awakening," we must have human environments in which to live, not the maladaptive structures that pass for places of learning in most educational institutions today. That means that components such as furniture, rugs, paintings, fireplaces, lighting, windows, and gardens need to be seen not as "amenities" or "accessories" but as integral parts of socio-educational space. It is not enough to provide students with telephone booths in the library (sometimes referred to as "carrels") and furnish some space in the basement next to the boiler room with tables and chairs and a sandwich dispensing machine and expect that somehow their academic lives will be enhanced.

Where it is necessary to have large spaces where many people can meet, it is wasteful to build lavish auditoriums; "We want places where there is just a beautiful blank floor and beautiful blank walls," Buckminster Fuller has suggested, "upon which to cast our pictures or apply crayons." 167 His geodesic domes are ideally suited to this purpose and they also can provide us with movable, transformable environments that will become increasingly important as our educational institutions become actively involved with the problems of urban centers and rumal areas.

We are just beginning to realize that our environments aren't just shelters from the wind and rain but new languages with the power to radically alter our consciousness and sensibility:

Get ready the greatest new educational facility ... assuming that any dreamable vision of technical advance will be a reality and man is about to demonstrate competence beyond our estimates of yesterday and today. ${ }^{108}$

166. Wright Faith in Your Own Individually, 98 HOUSE BEAUTrFuL 270, 302.

167. R. B. Fuller, Education Automation 86 (1962).

168. Id. 87 . 


\section{The Whole Man: The Interdisciplinary Study of Law}

It is apparent by now that if the law is to concern itself with human problems, our schools cannot endure in self-contained enclosures. As Muzafer Sherif noted at the recent Symposium on Problems of Interdisciplinary Relationships, "man does not arrange his problems or divide them up neatly along lines laid down by academic disciplines."103 There is, he observed, an "irreversible trend" toward interdisciplinary programs in the graduate and professional schools. ${ }^{170}$ In the law schools in particular, the question is no longer whether we will have them, but when, how, and how much?

Part of the problem with many of the interdisciplinary ventures that are already under way in the law schools is that their fruits have been largely irrelevant to the concerns of the law, or, if relevant, seem to add little understanding to what most law professors believed they already knew anyway. ${ }^{171}$ There is, of course, an edge of arrogance that most lawyers will never quite get over, but our ethnocentrism is by no means unique, ${ }^{172}$ and in some instances the resistance to collaboration is based on a healthy skepticism. Consider, for example, the joint ventures of psychiatrists and law professors that have been undertaken at several law schools in the past decade. In almost every instance, the psychoanalytical model has been dominant. With its emphasis upon individual and intraphysic phenomena, psychoanalytical theory is uncongenial to law, which is primarily concerned with the behavior of men in social settings- with their interaction in groups and their transactions with members of other groups. That is not to say that the psychoanalytical model is dispensable, but only that in the absence of an integrated theory of interactional and transactional processes, psychoanalysis alone has little relevance to the statement and resolution of legal problems. In focusing then on the deficiencies of Freudian psychodynamics, it is important not to throw the baby out with the bath water. We need to continue to press our interdisciplinary efforts, but unless our pilgrimage into the promised land of science is spirited by a quest for new theoretical constructs and a common language that will place

169. Sherif, Interdisciplinary Coordination as a Validily Check: Retrospect and Prospects, in INTERDISCIPLINARY RELATIONSHIPS IN THE SOcIAL SCIENCES 7 (Ar. Sherif \& C. Sherif eds. 1969).

170. Id. 4.

171. See Kalven, The Quest for the Middle Range: Empirical Inquiry and Legal Policy, in IAw IN A ChangING AMrerica 59-62 (G. Hazard ed. 1963).

172. CAMrPBErL, Ethnocentrism of Disciplines and the Fish-Scale Mlodel of Omniscience, in INTERDISCIPLINARY RELATIONSHIPS IN THE SOCIAI SCIENCES 328 (A1. Sherif \& C. Sherif eds. 1969). 
the individual and his internal processes in the context of "social collectivities of experience,"173 our journey is likely to prove disappointing.

Much of the enthusiasm for interdisciplinary collaboration has celebrated the value of the methodological instruction and empirical dati with which the sciences can inform legal theory. This pneumatic optimism is inflated by at least two assumptions, both of which seem to me false. The first, as Harry Kalven has pointed out, ${ }^{174}$ is that once the empirical facts are established, the determination of the legal isstues will automatically follow. That is a myth which lawmakers tend to perpetuate because it gracefully avoids confrontation with the underlying moral and political issues. In times of crisis, the appointment of a President's Commission or the appropriation of large sums of money to fund empirical research are usually dramatic ways of rising to meet the challenge of contemporary social problems without doing anything about them. Changes in the laws relating to the death penalty, the treatment of criminal offenders, the police, juvenile behavior, social welfare administration, drug use and obscenity will not proceed from the accumulation of scientific data because the attitudes of most people toward these problems are not shaped by anything organized or coherent enough to be susceptible to management by the scientific imagination. Those attitudes are more often the expression of hostility between warring subcultures ${ }^{175}$ or the articulation of socially shared fan. tasies and hallucinations which the treatment of psychotic patients has demonstrated do not readily yield to the methods of logic or science. The retention and vigorous enforcement of the marijuana laws, for example, are not based on any serious belief that marijuana is more harmful than tobacco or alcohol, but reflects what McLuhan refers to as "the cultural aggression and revenge of a dying culture against its successor." 176 The effectuation of change, then, requires fewer exercises in scientific demonstration and greater skill in the management of interclass hostility and the treatment of collective delusion; it calls for less facility in the quantification of "facts" and more of an effort to put people in touch with the ultimate datum of human experience-the feelings which generate the values each of us hold and which ultimately lubricate the engine of social change.

The second assumption that I alluded to earlier is that lawyers have

173. R. LAING, The Politics of Experience 49 (1967).

174. See Kalven, supra note 171, at 66-67.

175. See J. GuSFIerd, Symbolic Crusade 4-12, 16-24, 11.98 (1963).

176. McLuhan, Interview, PLAYBoy, March 1969, at 53, 66. 
all the theoretical structures they need (or at least are capable of formulating the right questions) and only require the janitorial services of other disciplines to collect and profess the facts with which to confirm the visions they have already fashioned or to tidy up the compartments into which the law has forced the stuff of human experience. The intellectual arrogance of lawyers tends to blind them to the new perspectives with which other disciplines can illuminate legal problems that have become encrusted with larvyers' "commonsense" notions of social reality. In the area of criminal law administration, for example, one agenda that lawyers have prepared for interdisciplinary study proceeds on the assumption that we will somehow learn more about the "causes" of crime if we examine the personality, character, chromosomal structure and social class of individual offenders. ${ }^{177}$ The question as it is put by the lawyer-why is it that certain individuals act in bizarre and violent ways, and how can we control this behavior?defines crime at the outset in such a way as to make it unlikely that we will arrive at any clearer understanding of this phenomenon, whatever methods of the sciences we choose to apply. A number of psychiatrists, psychologists and sociologists are suggesting that it might make more sense to view the phenomenon of crime as a process of social interaction in which the legal process itself plays a critical role rather than seeing it as an objectively given form of individual conduct. This kind of perspective would require us to dismantle the entire conceptual apparatus of actus reus and mens rea and to begin to understand crime not as the behavior of an individual offender but as a complex set of offender-victim-police-court interactions and transactions. ${ }^{1 \mathrm{is}}$ We know, for example, that most homicides do not occur in the street, but in the home, and not between strangers, but between people who are close to each other. This suggests that homicide may be a symptom of dysfunctional patterns of interaction within a family, and that the subject of investigation and treatment ought to be the potentially homicidal family rather than a class of dangerous individual offenders. ${ }^{179}$ Similarly, an act of "juvenile delinquency," from an interactional perspective, may be viewed as a situation in which the juvenile is being "scape-goated" and is expressing an upset or disequilibrium within the

177. Cf. Gigeroff, Phenomenology and the Law, 7 Criminolocica 9 (19ơ).

178. See J. Mohr, Towards Phenomenological Models of Criminal Transactions: Actus Rues Reconsidered (mimeo 1965), cited in Macnaughton-Smith, The Second Code Touard (or Away From) a Theory of Grime and Delinquency, 7 Csminolocial 15, 21 (1969).

179. Cf. Cheek, Family Socialization Techniques and Deviant Behavior, 5 Fasur Process 199 (1966). 
entire family as a social unit. 180 The delinquent act "can be looked upon as the only 'safe' way of calling attention to an intolerable family situation."181 or it may ultimately be an effort to preserve self by leaving the family. Any effort by the child to identify more explicitly the real conflict in the family would be perceived as "disloyal" by other members of the family. Virginia Satir, one of the pioneers in the field of family therapy, has pointed out how a child in a dysfunctional family can become burdened with the responsibility of "living for his parents." When he tries to get validation of himself as an individual and to satisfy his own needs, his behavior is likely to be perceived as rebellious or delinquent..182 When the legal process is invoked as a method of dealing with this disturbance in the homeostatic mechanism of the family, the child is officially labeled as "delinquent," thereby confirming and perpetuating the family pattern of interaction and the resultant behavior of the child. In the administration of the legal process itself, the interaction between attorney-parents-probation officer-judge generates a network of "parental" coalitions against the juvenile defendant that has the effect of undermining his bargaining power and legal rights. Thus, recent efforts to afford greater protection to the juvenile by guaranteeing representation by counsel in delinquency proceedings, however high-sounding the rhetoric, become practically meaningless. ${ }^{183}$

My point is that the accumulation of empirical data will just acd more debris to the dead weight the law schools are already carrying in their train unless traffic with other disciplines occurs before further research is undertaken. Moreover, effective interdisciplinary integration is ultimately dependent upon the development of a unifying set of ecological models emphasizing the interactional processes of human behavior. If, to take another example, we view schizophrenia as a form of dis-ease of an entire social subsystem-the family-rather than as individual pathology calling for a change in the behavior of an individual or his removal from society, ${ }^{184}$ what happens to the meaning and function within the legal system of such labels as "insanity" and "mental illness"? What implications would an interactional analysis of mental

180. D. Langsley \& D. Kaplan, The Treatment of Families in Crasis 10 (1968),

181. Framo, Rationale and Techniques of Intensive Family Therapy, in INTENsIw: FaMiLl T Therapy 143, 155 (I. Boszormenyi-Nagy \& J. Framo eds. 1965).

182. V. SATIR, ConJOINT FAMILY TherAPY 60-61 (1968).

183. See Platt \& Friedman, The Limits of Advocacy: Occupational Hazards in Juvenile Court, 116 U. PA. REv. 1156, 1176.84 (1968).

184. See Bateson, Jackson, Haley \& Weakland, Toward a Theory of Schizophrenia, 1 Behavioral Science 251 (1956); Wynne, Ryckoff \& Hirsch, Pseudomuttality in Fimily Relationships of Schizophrenics, 21 PSYCHIATRY 205 (1958); R. LAING \& A. EsTERSON, Sanity, MLAdess aNd the FaMilly (1964). 
illness have for a legal order that authorizes the institutionalization of one member of a dysfunctional family on the petition of another?'38 And what new problems are raised for "rehabilitation" models of control over individual conduct if we discover that certain forms of psychotic behavior actually involve a positive process of disintegration that constitutes the first step toward personal growth ${ }^{180}$ and that efforts to reintegrate the "identified patient" back into the family, without treating the entire family as a family may be disastrous because the family has a vested interest in keeping the patient "sick"? The current predilection of many lawmakers for systems of civil commitment and preventive detention as procedures for dealing with "dangerous" and "sick" persons pose grave risks to civil liberties not only because of the absence of safeguards normally associated with the criminal process, but because of the tendency to impute "dangerousness" or "illness" to an individual when the threat comes not from fear of physical violence, but from the "organizational threat" he presents to existing social arrangements and values and the consequent "need to justify collective action against him."187 We have become so accustomed to focussing on individual delusional behavior that we have become insensitive to the dangers that attend the formation of the collective fantasies and hallucinations that dominate our perceptions of the unholy trinity of crime, madness and evil. 188

How, then, shall we proceed in formulating an agenda for the interdisciplinary study of law? Whatever we eventually decide to do, we should not allow ourselves to be deluded into believing that interdisciplinary competence can be achieved by providing law students with temporary visas to visit the outlying provinces of the psychology, sociology or political science departments or even by sponsoring more formal "joint-degree" programs in which law students would combine courses in another department with some of the more traditional offerings in the law school. Aside from the problems generated by departmental prerequisites, the highly arbitrary organization of content into separate departments in the University itself defeats the very purpose of interdisciplinary study. The insularity and intense "nationalism" of

185. See, e.g., N.Y. Mental HyGIene LAw \& 124(2) (Mckinney Supp. 1969). See generally F. Imndian \& D. MaIntyre, The Mentally Disabled aNd the Law 23, 49.55 (1961).

186. See K. Dabrowser, Personaltiy Shaplng Throvgh Positive Dismiecration 77 (1967).

187. Lemert, Paranoia and the Dynamics of Exclusion, 25 Socrouetsx 2, (1962).

188. See M. Foucault, MLAdNESS and Civinization 205 (1965). 
each department, as Donald Campbell has recently explained ${ }_{2}{ }^{180}$ tendls to foster an acute hostility to ather disciplines and to discourage any crossing of disciplinary lines. Moreover, many of the courses affered in other departments present a pretty bland fare at the undergradunte level, and even many of the graduate courses are not immediately relevant to the concerns of lawyers. In psychology departments, for example, Andrew Watson has noted, ${ }^{180}$ there is often a large order of experimental psychology which has little value to lawyers who are more immediately and clinically concerned with problems of human behavior.

"Interdisciplinary integration," in Campbell's words, "has to take place within single minds." 101 It is not enough to marry psychology and law and then leave it to the Lord to make them live together in some vital and relevant way. Unless conceptual material and empirical hardware from other disciplines are carefully tooled and fitted to specific issues or areas in the law, an interdisciplinary program will tend to become a hodge-podge of unrelated concepts. Even team-teaching will not solve our problems unless there is an overlap of concerns and knowledge, a common language and a personal rapport between the individuals involved. One route we might travel, suggested by lirancis Allen, is to develop institutional arrangements designed to encourage and advance self-education by members of our own faculties in disciplinary areas outside the formal boundaries of the law. ${ }^{102}$ The difficulty here, as in joint-degree programs for students, is that unless law professors are freed from the constraint of pursuing traditional academic routes as a condition of securing legitimacy for their interdisciplinary competence within the academic community, such in program is not likely to succeed.

There are a host of other objections that can be, and have been raised, to undertaking interdisciplinary ventures in the law schools. A GAME OF CHESS: The law has been seduced by the sciences before, only to be awakened in later years to the folly of its innocent

189. Campbell, supra note 172 , at 336 .

190. Watson, The Law and Behavioral Science Project at the University of Pcnu= sylvania: A Psychiatrist on the Law Faculty, 11 J. OF LEGAL EDucATION 73, 74 (1958).

191. Campbell, supra note 172 , at 340 . This is the substance of comments made by Robert Dubin, Research Professor of Sociology at the University of Oregon, and several others at a symposium on problems of interdisciplinary relationships held in 1967. Sec Dubin, Contiguous Problem Analysis: An Approach to Systematic Theories about Sacial Organization, in INTERDISCIPLINARY RELATIONSHIPS IN THE SOCIAL ScIENCES 65 (M. Sherlf \& C. Sherif eds. 1969).

192. Allen, One Aspect of the Problem of Relevance in Legal Edtucation, 54 U. VA. L. REv. 595, 600 (1968). 
optimism. ${ }^{193}$ CHEGK. No law school has been successful to date in developing a viable model of interdisciplinary study. CHECK. It is difficult to find people who are prepared to devote the time and resources to developing interdisciplinary competence. CHECK. There are inadequate finàncial resources àvailable to support empirical research or to free faculty members for a sufficient period of time to develop the kind of integration we need. CHEGKMATE.

The cabinet of gloom, perhaps, contains some good medicine for that insuperable innocence (to which I have succumbed at times) which speaks glibly-almost magically-of interdisciplinary programs, as if one could be invoked by a mere vote of the faculty. Some of the resistance to interdisciplinary collaboration, I suspect, has been generated by a certain reluctance of the gatekeepers to permit strangers to enter that stately and orderly mansion of legal education in which we have all been living so comfortably. But the trouble is that many of our house guests are dying of boredom, especially on the second and third floors, and their boredom may have something to do with serious defects in the structure. Abraham Goldstein is right when he says that for many of our students who have heard "the promise of interdisciplinary adventure and social action so much in the air these days, it comes as a cruel disappointment to find law school very much like college-except that its organization is more random and archaic."101 As social problems proliferate, traditional legal education, aggressively abstract and perversely indifferent to the findings of the social and behavioral sciences concerning the human condition, is in serious danger of becoming a monumental irrelevancy in the process of social changie.

\section{Traditional Legal Education: The Future of an Illusion}

An illusion is not the same as an error, it is indeed not necessarily an error .... It is characteristic of the illusion that it is derived from men's wishes; in this it approaches the psychiatric delusion, but it is to be distinguished from this, quite apart from the more complicated structure of the latter.... [W] call a belief an illusion when wish-fulfilment is a prominent factor in its motivation, while disregarding its relations to reality, just as the illusion itself is.

-Sigmund Freud ${ }^{105}$

193. See Kalven, supra note 171 , at 58-63.

194. A. Goldstein, The Unfulfilled Promise of Legal Education, in LAw is a Chascise ANIERICA 157, 162 (G. Hazard ed. 1968).

195. S. Freud, The Future of AN Illusion 5t-55 (W. Robson-Scott transl. 1928). 
Most members of the law teaching profession today, I am sure, will agree that there is a need for some improvement in the quality of legal education, but the overwhelming majority is committed to the belief that our educational process is basically sound. The "Socratic dialogue"; the casebook method (at least in the first year); the content of the firstyear curriculum; the emphasis upon intellectual rigor and ruthless analysis of argument; the conviction that an emotional approach to the law is inappropriate; the desirability of retaining "objective" measures of relative performance; the importance of learning to "think like a lawyer"; the assumption that students do not know what is "best" for them but that teachers do-these are some of the canons of the theology of orthodox legal education, dissent from which is regarded as heresy.

Each year, the entering class at every law school is subjected to the ritual of the orientation lecture in which the law novitiates receive the credo from the high priests of legal education. They are told that the Law, like the Lord, is rigorous, exacting and uncompromising in the demands it will make on their lives for the next three years. And while those who are married may find the course somewhat less painful, the implicit admonition to that forgotten legion of women, the law wives, is that unless they learn to accept the law as a "jealous mistress," they would do well to get a divorce. For the students, the message is that the life that lies before them is difficult and set with hazards from which only the blessings of the faculty can protect them, and that the benevolence of the faculty is perishable and must, like our daily bread, be earned anew each day. ${ }^{100}$

The problem with the sacrament of self-sacrifice is that it requires the sacrifice of yourself, the thing which curiously "the world is least apt to inquire about and . . . of all things the most dangerous for a man to let people notice that he has ...."107 Last night, I talked to a friend who was a law student when I started teaching and I wondered whether we would see any real innovation in legal education in the next twenty-five years. Adapting a passage from Kierkegaard, he said that law school teaches students to deal with every conceivable loss, that of an arm, a leg, five dollars, a wife-every one, that is, but the most important, the loss of one's self, which "may pass off as quietly as if it were nothing . . . ."108

196. This is a paraphrase of an observation by J. Holt, How Children FAll 180 (1964).

197. S. KierkegaARd, The Sickness unto Death 165 (W. Lowric transl. 19.11).

198. Id. 
Today, the desire to make radical change, whether it be political or social or educational change, is regarded as one of those peculiarities of the "young"- a symptom which, like rock and sexuality and hair, will pass when the "young" grow older. I am sick of seeing teachers attempt to soothe dissident students into a stupor with patronizing talk about the idealism of youth. Some of them are sincerely touched by the idealism of their progeny; but in truth, as one astute observer has remarked, "the 'young' are economic, social and sexual threats, and [their parents and teachers] ... really do hate them, as much because they are so resolutely moral as anything else."100

The principal difference between the New Politics and the Old Politics is that the spirit of the former is committed to tying political change to a revolution in personal life; that is, "politics ... is the way somebody lives his life." 200 The failure to understand "the indispensability of a radical personal culture or life-style," Susan Sontag suggests, is perhaps what made the Old Left

so vulnerable to piecemeal co-option by the liberal establishment .... Bending the mind and shaking loose the body makes someone a less willing functionary of the bureaucratic machine. Rock, grass, better orgasms, freaky clothes, grooving on naturereally grooving on anything-unfits, maladapts a person for the American way of life..$^{201}$

The real "unliberated zones" are the interiors of our orwn personal lives.

There will undoubtedly be movement in legal education. Even a sloth moves if prodded long enough. But to what purpose will we integrate existing psychology courses (for example) into the law curriculum, or develop joint degree programs, when one of the country's most eminent psychologists has recently said of academic psychology that it is probably "leading every field in dogmatism, rigidity, narrow orthodoxy, and scorn of social involvement"? continue to pretend that the traditional methods and concepts of the law are adaptable to the needs of the poor when those who have had any experience with legal services programs acknowledge that the contributions of the conventional strategies of civil and criminal justice

199. Anonymous, quoted in Jerome, The American Academy 1970, Ciunice in Hiciens Education Sept.-Oct. 1969, at 10,37.

200. A. Hoffaran, Revolution FOR the HeLl of It 59 (1968).

201. S. Sontag, Some Thoughts on the Right Way (for us) 10 Love the Cuban Revolution, RAMPARTs, April 1969, at 6.

202. Rogers, The Increasing Involvement of the Psychologist in Social Problems: Some Comments, Positive \& Negative, 5 Journal of Applied Berunoral Science 3 (1969). 
to social justice is "diffuse, microcosmic and dull"?203 One might as well say that our schools are preparing students to write novels by teaching them the alphabet.

I am disturbed by the present drift of legal education, not in the way that loud noises and sudden jolts are disturbing, but as countless nights of dreamless sleep are disturbing. Unless we begin to perceive the law school as a community of human beings living in the here-and. now, we may find that our educational theology is an illusion and that the promised professional after-life is but another form of denth. The question, then, is not whether we are moving, but whether in moving we are growing, or if, like some great tortoise that begins its last journey to the sea, we are moving only because we are dying.

203. Hazard, Social Justice Through Civil Justice, 36 U. CH. L. REv. 699, 712 (1969), 